\title{
Alteration of Nutrient Substrates and Absence of Seawater Due to Coastal Embankments Affects Soil Microbial Communities in Salt Marshes of Eastern China
}

Hongyu Feng ( $\nabla$ hongyufeng@smail.nju.edu.cn )

Nanjing University https://orcid.org/0000-0001-9658-3498

Yajun Qiao

Nanjing University

Lu Xia

Nanjing University

Wen Yang

Shaanxi Normal University

Yongqiang Zhao

Yancheng Wetland Natural Reserve for Rare Birds

Nasreen Jeelani

Nanjing University

Shuqing An

Nanjing University

\section{Research Article}

Keywords: Bacterial and archaeal diversity, ecosystem N cycles, high-throughput sequencing, soil bacterial and archaeal community composition, 16S rRNA gene

Posted Date: July 20th, 2021

DOI: https://doi.org/10.21203/rs.3.rs-707097/v1

License: (c) (i) This work is licensed under a Creative Commons Attribution 4.0 International License. Read Full License 


\section{Abstract}

Aims: Although the influence of coastal embankments on soil physicochemical properties and carbon (C) and nitrogen $(\mathrm{N})$ cycling has been widely studied, the mechanisms of their effects on the soil microbial ecology are still poorly understood. Thus, the aim of this study was to investigate variations in soil bacterial and archaeal communities between natural and embanked saltmarshes, as well as the determinants that drive these variations.

Methods: 16S rRNA gene sequence analysis was performed to assess the impacts of embankments on the bacterial and archaeal communities of the invasive Spartina alterniflora Loisel., as well as native Suaeda salsa (L.) Pall. and Phragmites australis (Cav.) Trin. ex Steud. saltmarshes in the coastal China.

Results: Embankments significantly decreased the Simpson diversity index of the S. alterniflora saltmarsh, while increasing the OTU richness in the $P$. australis saltmarsh. Additionally, the bacterial and archaeal community compositions in the embanked $S$. alterniflora and $P$. australis saltmarshes were considerably modified. However, no variations were found between the bacterial and archaeal communities of the natural and embanked $S$. salsa saltmarshes.

Conclusions: These results were possibly because embankments decreased the soil nutrient substrates (e.g., soil organic $\mathrm{C}$ and $\mathrm{N}$ ) dramatically in the $S$. alterniflora saltmarsh, while increased soil nutrient substrates significantly in the $P$. australis saltmarsh. However, embankments had a negligible effect on the soil nutrient substrates in the $S$. salsa saltmarsh. Moreover, embankments increased the abundance of Betaproteobacteria, and decreased the abundance of sulfur- and sodium-dependent bacteria due to the dramatic change in soil physicochemical properties.

\section{Introduction}

Coastal land reclamation through the establishment of coastal embankments has caused considerable ecological problems in natural coastal ecosystems. For instance, they have greatly threatened coastal habitats and biodiversity (particularly the soil microbial communities) and altered ecosystem processes and functions (particularly C and N cycling) (Dick and Osunkoya 2000; Ma et al. 2014; Yang et al. 2016). Soil bacteria are the most abundant and diverse group of soil microbes, with archaea also being numerically abundant (Buckley and Schmidt 2002; Fierer et al. 2007). Both play a crucial role in the transformation of soil nutrients and in the biogeochemical cycles (Nannipieri et al. 2003; Philippot et al. 2013; DeCrappeo et al. 2017; Gryta and Frac 2020). Moreover, bacteria and archaea are sensitive soil elements that can rapidly detect and react to various conditions and changes in the soil environment (Gryta and Frac 2020). Although the effects of coastal embankments on aboveground ecosystems have been widely studied, their potential advantages and risks to belowground ecosystems, particularly soil bacterial and archaeal communities, have not been fully estimated.

Soil nutrient substrates are one of the primary driving factors for bacterial and archaeal diversity, richness, and community composition (Peralta et al. 2013; Sun et al. 2021; Kuang et al. 2021). In 
particular, soil organic $\mathrm{C}$ and $\mathrm{N}$ (SOC and SON, respectively) decomposition provides energy and nutrition for soil microorganisms; thus, soil $\mathrm{C}$ and $\mathrm{N}$ are overarching driving factors for the growth of soil bacteria and archaea (Zechmeister-Boltenstern et al. 2015; Yang et al. 2020). However, various bacterial and archaeal taxa respond differently to nutrient availability. For instance, copiotrophic bacteria (e.g., phylum Bacteroidetes) prefer nutrient-rich environments, as labile organic C and N (LOC and LON, respectively) inputs can significantly promote their growth (Fierer et al. 2007; Newton and McMahon 2011; Philippot et al. 2013). In contrast, because LOC and LON inputs have the opposite effect on oligotrophic bacteria (e.g., phylum Actinobacteria), these organisms prefer nutrient-poor environments (Podosokorskaya et al. 2013; Trivedi et al. 2013; Xie et al. 2014; Verzeaux et al. 2016). Additionally, high quality organic matter (e.g., with low $\mathrm{C} / \mathrm{N}$ rate) has been reported to increase the relative abundance of archaea (e.g., phylum Crenarchaeota) (Bates et al. 2011). Coastal embankments can either increase, decrease, or have negligible effects on soil $\mathrm{C}$ and $\mathrm{N}$ sequestration, while shifting the availability of soil $\mathrm{C}$ and $\mathrm{N}$ by altering the inputs of plant residues in the soil (Laudicina et al. 2009; Cui et al. 2012; Wang et al. 2014). Therefore, the responses of soil bacterial and archaeal communities to coastal embankments may differ depending on the shifts in nutrient substrates caused by these structures.

Soil microbial communities are considerably influenced by biotic (e.g., the quantity and quality of plant materials) (Angel et al. 2010) and abiotic (e.g., climate, soil type, and soil physicochemical properties) factors (Bainard et al. 2016; Nguyen et al. 2018). Plant properties, such as the aboveground and belowground biomass, strongly affect soil bacteria and archaea (Brotosudarmo et al. 2014a; Li et al. 2015; Urbanová et al. 2015); the former influences the growth of photosynthetic bacteria (PSB) by affecting the amount of light that reaches the soil (He et al. 2012; Li et al. 2014a; Brotosudarmo et al. 2015), and the latter dictates the availability of $C$ and $N$, in addition to providing unique environments for soil bacteria and archaea (Kuske et al. 2002; Urbanová et al. 2015). Soil physicochemical properties critically influence bacterial and archaeal communities (Yang et al. 2020; Sun et al. 2021; Zhang et al. 2021). For instance, soil pH can affect their community compositions, as the relative abundance of bacteria increases with increasing soil pH (Högberg et al. 2007; Peralta et al. 2013; Sun et al. 2021). Similarly, soil salinity restricts the growth of bacteria and archaea by limiting water availability (Rath and Rousk 2015; Zhang et al. 2021). Additionally, soil moisture is a vital driver of soil bacterial community composition, especially the proportion of aerobic and anaerobic bacteria, because it affects soil aeration conditions (Guo and Zhou 2020; Yang et al. 2020; Sun et al. 2021). Notably, the establishment of coastal embankments considerably shifts the net primary production and physicochemical properties of coastal wetland soils (Yang et al. 2016; Yang et al. 2019). Thus, the identification of biotic and abiotic factors that affect soil bacterial and archaeal communities in environments with coastal embankments may improve our understanding of how these structures have impacted bacterial and archaeal communities in soils.

China has been constructing increasingly intensive coastal embankments, with approximately $60 \%$ of the total length of its mainland coastline being enclosed by thousands of kilometers of embankments (Ma et al. 2014; Sun et al. 2015). The Jiangsu province has the highest abundance of coastal wetlands and embankments in Eastern China (Chung et al. 2004). Currently, a large portion of the natural coastal 
wetlands in this region have been reclaimed by embankments (i.e., construction of dikes, seawalls, and barriers along the coastline), fishponds, farmlands, and unban lands (Liu 2018). The results of previous studies that have focused on the impacts of the conversion of coastal wetland to other land-use types on soil microbial communities are inconsistent (Xu et al. 2017; Li et al. 2019; Yang et al. 2019). For instance, studies have documented both an increase and decrease in bacterial abundance and diversity in the soil, especially the relative abundance of Proteobacteria, due to the conversion of coastal wetlands into farmlands (Xu et al. 2017; Li et al. 2019; Yang et al. 2019). These inconsistent results may be caused by multiple factors, such as differences in land reclamation history and intensity and land-use patterns following the establishment of coastal embankments (Yang et al. 2016). Additionally, it is difficult to distinguish between the effects of coastal embankments and subsequent land-use conversions (e.g., fishponds and agricultural and urban land) on soil microbial communities (Bai et al. 2013; Bu et al. 2015). Therefore, the impact of coastal embankments without associated land-use changes on soil bacterial and archaeal communities of coastal wetlands is still unknown. We hypothesized that the establishment of coastal embankments without land-use changes would shift the diversity and composition of bacterial and archaeal communities by changing the soil physicochemical properties and nutrient substrates. To verify our hypothesis, we compared the diversity and composition of bacterial and archaeal communities of embanked and adjacent unembanked Spartina alterniflora Loisel., Suaeda salsa (L.) Pall., and Phragmites australis (Cav.) Trin. ex Steud. salt marshes by extracting and sequencing their 16S rRNA genes; in addition, the plant biomass and soil properties (i.e., soil moisture, salinity, pH, SOC, LOC, water-soluble organic C (WSOC), SON, LON, and water-soluble organic N (WSON)) of embanked and adjacent unembanked $S$. alterniflora, $S$. salsa, and $P$. australis salt marshes along Jiangsu coasts were also compared. The aim of this study was to: (1) understand whether the establishment of coastal embankments without land-use changes influences the diversity and composition of bacterial and archaeal communities, and (2) if so, identify the factors that drive those variations.

\section{Methods}

\subsection{Study sites}

The study was conducted in coastal Yancheng $\left(32^{\circ} 48^{\prime}-34^{\circ} 29^{\prime} \mathrm{N}, 119^{\circ} 53^{\prime}-121^{\circ} 18^{\prime} \mathrm{E}\right)$, Jiangsu province (Fig. 1). The mean annual temperature and precipitation of this region are $13.7-14.6^{\circ} \mathrm{C}$ and $980-1,070$ $\mathrm{mm}$, respectively (Wang and Liu 2005). The seawater salinity is approximately $30.9 \%$ (Yang et al. 2020). S. alterniflora, $S$. salsa, and $P$. australis salt marshes are the main vegetation types in coastal Jiangsu. $S$. alterniflora is an invasive perennial grass that was introduced in China from North America in 1979, while S. salsa and P. australis are native to coastal Jiangsu (An et al. 2007; Qin and Li 2012).

The coastal wetlands of Yancheng are an important stop on the migration route of shorebirds between East Asia and Australia. This is also the largest wintering area of the endangered Red-crowned Cranes (Grus japonensis) (Liu et al. 2010; Wang et al. 2019b). However, since its introduction, S. alterniflora has been outcompeting the native plants for resources such as space; therefore, some embankments have been constructed to control the expansion of S. alterniflora (Wang and Liu 2005; An et al. 2007; Qin and Li 
2012; Wang et al. 2019a, b). These coastal embankments were covered with waterproof material, and the land-use in the embanked region did not change at the study sites.

\subsection{Field sampling}

In September 2016, four parallel transects $(40 \times 40 \mathrm{~m})$ were constructed in embanked S. alterniflora (ESA), S. salsa (ESS), and P. australis (EPA) salt marshes and unembanked S. alterniflora (USA), S. salsa (USS), and $P$. australis (UPA) salt marshes (Fig. 1). We randomly selected three plots $(2 \times 2 \mathrm{~m})$ in each transect, and soil samples were randomly collected from three points $(5 \mathrm{~cm}$ diameter $\times 30 \mathrm{~cm}$ depth) in each plot. All soil samples from the same plots were mixed intensively to form the final soil sample. Finally, 24 soil samples (four replicates $\times$ six treatments) were obtained. All roots were removed from the soil samples and ground in the laboratory. The soil samples were divided into four subsamples. The first soil subsample was placed in an aluminum box to determine soil moisture. The second was air-dried, passed through a $1 \mathrm{~mm}$ sieve, and then used for the measurement of soil pH, salinity, SOC, and SON. The third was passed through a $2 \mathrm{~mm}$ sieve and preserved at $4^{\circ} \mathrm{C}$, and then used for the determination of WSOC and WSON concentrations. The fourth soil subsample was passed through a $2 \mathrm{~mm}$ sieve and stored at $-80^{\circ} \mathrm{C}$ for use in molecular analyses.

Three quadrats $(50 \times 50 \mathrm{~cm}$ ) were constructed at each transect to collect plant samples, including leaves, stems, litter, and roots. Roots were collected in each transect from three blocks of soil $(10 \mathrm{~cm}$ length $\times 10$ $\mathrm{cm}$ width $\times 30 \mathrm{~cm}$ depth), which were sifted through a $15 \mathrm{~mm}$ sieve. The aboveground biomass was calculated as the sum of the leaf, stem, and litter biomass and the belowground biomass was represented by the root biomass.

\subsection{Soil and plant properties}

Soil $\mathrm{pH}$ was determined in a 1:2.5 soil:water suspension using a pH meter, and the soil salinity was determined in a 1:5 soil:water suspension using a conductivity meter (Yang et al. 2016). The total inorganic $\mathrm{C}$ and $\mathrm{N}$ were obtained from $10 \mathrm{~g}$ of air-dried soil samples using $1 \mathrm{M} \mathrm{HCl}$. Recalcitrant organic $\mathrm{C}$ (ROC) and recalcitrant organic N (RON) were measured using the acid hydrolysis method (Rovira and Vallejo 2002; Yang et al. 2016). The soil SOC, SON, ROC, and RON were determined using an Elementar Vario Micro CHNS analyzer (Elementar Analysensystem GmbH, Langenselbold, Germany). The LOC and LON were calculated using the following equations:

$\mathrm{LOC}=\mathrm{SOC}-\mathrm{ROC}(1)$

LON $=$ SON - RON (2)

The WSOC and WSON were determined following a previously established method (Cabrera and Beare 1993; Yu et al. 1994; Yang et al. 2016). In addition, the leaf, stem, litter, and root biomass were measured after oven-drying at $65^{\circ} \mathrm{C}$.

\subsection{DNA extraction and Polymerase Chain Reactions (PCR)}


Total genomic DNA from samples was extracted using the Omega Bio-Tek E.Z.N.A. Soil DNA Extraction Kit (Omega Bio-Tek, Atlanta, USA) following the manufacturer's protocol. The DNA concentration and purity were monitored using $1 \%$ agarose gels. According to the concentration, DNA was diluted to $1 \mathrm{ng} / \mu \mathrm{L}$ using sterile water.

The 16S rRNA genes of distinct regions (V3-V4/16S) were amplified using the 338F primer (5'ACTCCTACGGGAGGCAGCA-3') and 806R primer (5'- GGACTACHVGGGTWTCTAAT-3') (Fierer et al. 2005). All PCR reactions were carried out with $15 \mu \mathrm{L}$ of Phusion High-Fidelity PCR Master Mix (New England Biolabs, USA), $0.2 \mu \mathrm{M}$ of forward and reverse primers each, and approximately $10 \mathrm{ng}$ template DNA. Thermal cycling consisted of initial denaturation at $98^{\circ} \mathrm{C}$ for $1 \mathrm{~min}$, followed by 30 cycles of denaturation at $98^{\circ} \mathrm{C}$ for $10 \mathrm{~s}$, annealing at $50^{\circ} \mathrm{C}$ for $30 \mathrm{~s}$, and elongation at $72^{\circ} \mathrm{C}$ for $30 \mathrm{~s}$. Finally, it was held at $72^{\circ} \mathrm{C}$ for 5 min.

\subsection{Quantification and sequencing of PCR products}

Equal volume of $1 \mathrm{X}$ loading buffer (containing SYBR ${ }^{\text {TM }}$ Green) was mixed with PCR products and electrophoresed on $2 \%$ agarose gel for detection. The PCR products were mixed at equidensity ratios. Then, the PCR products were purified using the Qiagen Gel Extraction Kit, according to the manufacturer's instructions (Qiagen, Germany).

Sequencing libraries were generated using the TruSeq DNA PCR-Free Sample Preparation Kit (Illumina, San Diego, CA, USA) following the manufacturer's recommendations, and index codes were added. The library quality was assessed on the Qubit 2.0 Fluorometer (Thermo Scientific, CN) and Agilent Bioanalyzer 2100 system (Agilent, Santa Clara, CA, USA). Finally, the library was sequenced on an Illumina NovaSeq platform, and 250 bp paired-end reads were generated.

\subsection{Data analysis}

Paired-end reads were assigned to soil subsamples based on their unique barcodes and truncated by cutting off the barcode and primer sequences. Paired-end reads were merged using FLASh v.1.2.7 (Center for Computational Biology, Baltimore, MD, USA), when at least some of the reads overlapped the read generated from the opposite end of the same DNA fragment, and the splicing sequences were called raw tags (Magoč and Salzberg 2011). Quality filtering of raw tags was performed under specific filtering conditions to obtain high-quality clean tags according to the QIIME v.1.9.1 quality-controlled process (Caporaso et al. 2010; Bokulich et al. 2013). The tags were compared with the Silva database using the UCHIME algorithm to detect and remove chimera sequences (Edgar et al. 2011; Haas et al. 2011). Subsequently, effective tags were obtained.

Sequence analysis was performed using Uparse software v.7.0.1001 (Edgar 2013). Sequences with $\geq$ $97 \%$ similarity were assigned to the same optical transform unit (OTU). A representative sequence of each OTU was screened for further annotation. For each representative sequence, the Silva Database was used based on the Mothur algorithm to annotate taxonomic information (Quast et al. 2013). To study the phylogenetic relationship of different OTUs and the difference in the dominant species in different 
samples, multiple sequence alignment was conducted using MUSCLE software v.3.8.31 (Edgar 2004). OTU abundance information was normalized using a standard with sequence number corresponding to the sample with the least sequences. Subsequent analyses of alpha and beta diversity were performed based on the normalized data output.

Indices were calculated with QIIME v.1.9.1 and displayed with R software v.2.15.3 (Caporaso et al. 2010). The Simpson index was used to assess community diversity, and principal coordinate analysis (PCOA) and analysis of similarities (ANOSIM) were performed to detect differences in community structure (beta diversity). Significant differences in the soil bacterial and archaeal communities between USA and ESA, USS and ESS, or UPA and EPA were evaluated by linear discriminant analysis (LDA) effect size (LEfSe) (Segata et al. 2011). Cladograms were made showing the differences in the microbial lineages between USA and ESA, ESS and ESS, or UPA and EPA with LDA values of 4 or higher.

\subsection{Statistical analysis}

The influence of environmental factors on the bacterial and archaeal community structures at the phylum, class, order, family, genus, and species levels was evaluated with redundancy analyses (RDA) using CANOCO v.5.0 (Wageningen University \& Research, Wageningen, Netherlands). The Monte Carlo permutation test (499 permutations) was performed and statistical significance was set at 0.05 .

Statistical software SPSS 22.0 (IBM Corp, Armonk, New York, USA) was used to analyze the data. The impacts of coastal embankments on the plant biomass, soil physicochemical properties, Simpson index, OTU richness, and relative abundance of dominant bacteria and archaea in USA, ESA, USS, ESS, UPS, and EPS were evaluated using one-way ANOVA (analysis of variance). The relationships between soil bacterial and archaeal diversity and absolute abundance with plant biomass and soil properties were evaluated using Pearson's correlation analysis. In addition, structural equation modeling (SEM) was carried out to determine the direct and indirect effects of coastal embankments on parameters related to the soil bacterial and archaeal absolute abundance following the expectations of the a priori model (Fig. S1); the normality of all endogenous variables and the overall model was tested and verified. The normaldistribution-based maximum likelihood method was used for parameter estimation (Boldea and Magnus 2009). The best-fitting model was selected by sequentially removing non-significant paths $(p<0.05)$. The

overall goodness-of-fit for the model was tested using the chi-squared test $\left(\chi^{2}\right)$ and the root-mean-square error of approximation (RMSEA; $0 \leq$ RMSEA $\leq 0.05$ ) (Schermelleh-Engel et al. 2003). The SEM was carried out using Amos 22.0 (IBM Corp, SPSS, New York, USA).

\section{Results}

\subsection{Plant and soil properties}

The aboveground, belowground, and total biomass of ESA were $57.511 \%, 57.901 \%$, and $57.658 \%$ lower, respectively, than those of USA, while those of EPA were $59.126 \%, 175.560 \%$, and $109.143 \%$ lower, respectively, than those of UPA (Table 1). Additionally, the belowground biomass was $21.739 \%$ lower in 
ESS than in USS; however, there were no significant differences in the aboveground and total biomass between the ESS and USS (Table 1).

Table 1

Aboveground, belowground, and total biomass (mean $\pm S E, n=4$ ) in the unembanked and embanked Spartina alterniflora, Suaeda salsa, and Phragmites australis salt marshes. Different superscripted lowercase letters indicate statistical significance at $p<0.05$ between the unembanked and embanked ranges in the same plant salt marshes.

\begin{tabular}{|llll|}
\hline \multicolumn{3}{|c|}{ Biomass $\left(\mathbf{k g} \cdot \mathbf{m}^{-\mathbf{2}}\right)$} & \\
\hline & Aboveground & Belowground & Total \\
\hline USA & $3.921 \pm 0.320^{\mathrm{a}}$ & $2.373 \pm 0.379^{\mathrm{a}}$ & $6.294 \pm 0.175^{\mathrm{a}}$ \\
\hline ESA & $1.666 \pm 0.144^{\mathrm{b}}$ & $0.999 \pm 0.199^{\mathrm{b}}$ & $2.665 \pm 0.117^{\mathrm{b}}$ \\
\hline USS & $0.302 \pm 0.022^{\mathrm{a}}$ & $0.046 \pm 0.001^{\mathrm{a}}$ & $0.348 \pm 0.023^{\mathrm{a}}$ \\
\hline ESS & $0.271 \pm 0.010^{\mathrm{a}}$ & $0.036 \pm 0.003^{\mathrm{b}}$ & $0.307 \pm 0.012^{\mathrm{a}}$ \\
\hline UPA & $1.304 \pm 0.124^{\mathrm{a}}$ & $0.982 \pm 0.224^{\mathrm{a}}$ & $2.286 \pm 0.191^{\mathrm{a}}$ \\
\hline EPA & $2.075 \pm 0.315^{\mathrm{b}}$ & $2.706 \pm 0.388^{\mathrm{b}}$ & $4.781 \pm 0.686^{\mathrm{b}}$ \\
\hline $\begin{array}{l}\text { USA: unembanked } \text { S. alterniflora salt marsh; ESA: embanked S. alterniflora salt marsh; USS: } \\
\text { unembanked S. salsa salt marsh; ESS: embanked S. salsa salt marsh; UPA: unembanked P. australis } \\
\text { salt marsh; EPA: embanked P. australis salt marsh. }\end{array}$ \\
\hline
\end{tabular}

The soil moisture of ESA and ESS were significantly lower than those of USA and USS, while the soil moisture of EPA was significantly higher than that of UPA (Table 2). Additionally, the soil salinity was significantly lower in ESA, ESS, and EPA than in USA, USS, and UPA (Table 2). 
Table 2

Soil physicochemical properties (a) and concentrations of soil total, labile, and water-soluble organic C (b), and N (c) (mean \pm SE, $\mathrm{n}=4$ ) in the unembanked and embanked S. alterniflora, $S$. salsa, and P. australis salt marshes. Different superscripted lower-case letters indicate statistical significance at $p<0.05$ between the unembanked and embanked ranges in the same plant salt marsh.

\begin{tabular}{|c|c|c|c|c|}
\hline (a) & Moisture (\%) & \multicolumn{2}{|l|}{$\mathrm{pH}$} & Salinity (\%o) \\
\hline USA & $52.248 \pm 2.876^{a}$ & \multicolumn{2}{|c|}{$8.382 \pm 0.032^{\mathrm{a}}$} & $12.783 \pm 0.455^{a}$ \\
\hline ESA & $29.693 \pm 1.542 \rrbracket$ & \multicolumn{2}{|c|}{$9.148 \pm 0.040 \nabla$} & $2.399 \pm 0.137 \rrbracket$ \\
\hline USS & $27.617 \pm 0.665^{a}$ & \multicolumn{2}{|c|}{$8.843 \pm 0.034^{a}$} & $5.858 \pm 0.406^{a}$ \\
\hline ESS & $25.245 \pm 0.380 \rrbracket$ & \multicolumn{2}{|c|}{$9.001 \pm 0.023 \rrbracket$} & $4.880 \pm 0.188 \square$ \\
\hline UPA & $25.545 \pm 0.347^{a}$ & \multicolumn{2}{|c|}{$8.830 \pm 0.035^{a}$} & $4.164 \pm 0.160^{a}$ \\
\hline EPA & $33.601 \pm 3.360 \rrbracket$ & \multicolumn{2}{|c|}{$9.068 \pm 0.057 \rrbracket$} & $1.737 \pm 0.033 \rrbracket$ \\
\hline (b) & $\operatorname{sOC}\left(g \cdot \mathrm{kg}^{-1}\right)$ & \multicolumn{2}{|c|}{$\operatorname{LOC}\left(\mathrm{g} \cdot \mathrm{kg}^{-1}\right)$} & WSOC $\left(\mathrm{g} \cdot \mathrm{kg}^{-1}\right)$ \\
\hline USA & $7.343 \pm 0.738^{a}$ & \multicolumn{2}{|c|}{$1.418 \pm 0.190^{a}$} & $0.175 \pm 0.009^{a}$ \\
\hline ESA & $2.859 \pm 0.405 \rrbracket$ & \multicolumn{2}{|c|}{$0.651 \pm 0.156^{b}$} & $0.120 \pm 0.006^{a}$ \\
\hline USS & $2.520 \pm 0.464^{a}$ & \multicolumn{2}{|c|}{$0.835 \pm 0.274^{a}$} & $0.075 \pm 0.003^{a}$ \\
\hline ESS & $1.814 \pm 0.117^{a}$ & \multicolumn{2}{|c|}{$0.295 \pm 0.060^{a}$} & $0.076 \pm 0.003^{a}$ \\
\hline UPA & $3.432 \pm 0.300^{a}$ & \multicolumn{2}{|c|}{$1.772 \pm 0.185^{a}$} & $0.032 \pm 0.001^{a}$ \\
\hline EPA & $4.938 \pm 0.699 \rrbracket$ & \multicolumn{2}{|c|}{$1.969 \pm 0.228^{a}$} & $0.043 \pm 0.003 \rrbracket$ \\
\hline (c) & $\operatorname{SON}\left(g \cdot \mathrm{kg}^{-1}\right)$ & $\operatorname{LON}\left(\mathrm{g} \cdot \mathrm{kg}^{-1}\right)$ & WSON $\left(\mathrm{g} \cdot \mathrm{kg}^{-1}\right)$ & $\mathrm{C} / \mathrm{N}$ \\
\hline USA & $0.646 \pm 0.062^{a}$ & $0.347 \pm 0.042^{a}$ & $0.047 \pm 0.001^{a}$ & $11.308 \pm 0.249^{a}$ \\
\hline ESA & $0.250 \pm 0.036 \rrbracket$ & $0.135 \pm 0.028^{b}$ & $0.044 \pm 0.001^{a}$ & $11.496 \pm 0.239^{a}$ \\
\hline USS & $0.271 \pm 0.048^{a}$ & $0.164 \pm 0.038^{a}$ & $0.054 \pm 0.001^{a}$ & $9.266 \pm 0.200^{a}$ \\
\hline ESS & $0.206 \pm 0.011^{a}$ & $0.084 \pm 0.008^{a}$ & $0.053 \pm 0.001^{a}$ & $8.787 \pm 0.149^{a}$ \\
\hline UPA & $0.232 \pm 0.026^{a}$ & $0.128 \pm 0.022^{a}$ & $0.053 \pm 0.001^{a}$ & $15.617 \pm 1.176^{a}$ \\
\hline EPA & $0.382 \pm 0.071^{b}$ & $0.215 \pm 0.058^{a}$ & $0.052 \pm 0.001^{a}$ & $14.316 \pm 1.022^{\mathrm{a}}$ \\
\hline $\begin{array}{l}\text { USA: } \\
\text { unem } \\
\text { salt } n \\
\text { watel }\end{array}$ & $\begin{array}{l}\text { mbanked } S \text {. alte } \\
\text { ked } S \text {. salsa sal } \\
\text { h; EPA: embank } \\
\text { uble organic C; } \subseteq\end{array}$ & $\begin{array}{l}\text { ora salt marsh; } \mathrm{E} \\
\text { rsh; ESS: emban } \\
\text { australis salt m } \\
\text { total organic N; }\end{array}$ & $\begin{array}{l}\text { embanked } S \text {. alte } \\
\text { S. salsa salt mar } \\
\text { ר. SOC, total orgar } \\
\text { V, labile organic N }\end{array}$ & $\begin{array}{l}\text { Tora salt marsh; USS: } \\
\text { JPA: unembanked P. australis } \\
\text {; LOC, labile organic C; WSOC } \\
\text { ON, water-soluble organic N. }\end{array}$ \\
\hline
\end{tabular}


The SOC, LOC, WSOC, SON, and LON concentrations of ESA were 61.065\%, 54.090\%, 31.429\%, 61.300\%, and $61.095 \%$ lower, respectively, than those of USA (Table 2 ). The SOC, WSOC, and SON were $43.881 \%$, $34.375 \%$, and $64.655 \%$ higher, respectively, in EPA than in UPA (Table 2). Additionally, there were no significant differences in the concentrations of SOC, LOC, WSOC, SON, LON, and WSON between the ESS and USS (Table 2).

\subsection{Alpha diversity of bacterial and archaeal communities}

The OTU richness in the EPA was significantly higher than that in the UPA, and the Simpson diversity index in the ESA was significantly lower than that in the USA $(p<0.05$; Fig. 2$)$. However, the OTU richness and the Simpson diversity index between the USS and ESS both were not significant ( $p \geq 0.05$; Fig. 2). Furthermore, the Pearson's correlation analysis of all salt marshes revealed that the variations in Simpson diversity indices were significantly positively correlated with soil moisture, SOC, SON, and LON (Fig. S2).

\subsection{Taxonomic composition of soil bacterial and archaeal communities}

The USA had an abundance of Deltaproteobacteria (from class to order, within the phylum Proteobacteria) and Epsilonproteobacteria (from class to order, within the phylum Proteobacteria), while the ESA had an abundance of Actinobacteria (from phylum to order), Betaproteobacteria (within the phylum Proteobacteria), and the order Xanthomonadales (from order to family, within the class Gammaproteobacteria, phylum Proteobacteria) (Fig. 3). Moreover, the absolute abundances of the phylum Chlorobi, and classes Ignavibacteria, Chlorobia (within the phylum Chlorobi), and Chloroflexi (within the phylum Chloroflexi) were significantly higher in the ESA than those in the USA $(p<0.05)$, whereas the absolute abundances of the phylum Fusobacteria and the class Rhodothermia (within the phylum Bacteroidetes) were significantly lower in the ESA than in the USA (Fig. 4).

The ESS had a high occurrence of Gammaproteobacteria (from class to family, within the phylum Proteobacteria) and the order Burkholderiales (within the class Betaproteobacteria) (Fig. 3).

The family Shewanellaceae (from family to genus, within the order Alteromonadales, class Gammaproteobacteria) was abundant in the UPA, while the Betaproteobacteria (from class to order), the order Pseudomonadales (within the class Gammaproteobacteria), and the family Chromatiaceae were abundant in the EPA (Fig. 3). Additionally, the absolute abundance of class 4C0d-2 (within the phylum Cyanobacteria) was significantly lower in the EPA than in the UPA ( $p<0.05$; Fig. 4).

\subsection{Beta diversity of soil bacterial and archaeal communities}

Bray-Curtis dissimilarity indices indicated the variations in the bacterial and archaeal communities between the USA and ESA and between UPA and EPA were 65.620\% $(p=0.0230)$ and 45.830\% $(p=$ 0.0460), respectively (Fig. 5). However, the variation in the bacterial and archaeal communities between the USS and ESS was not significant ( $p \geq 0.05$; Fig. 5). 


\subsection{Controls on the soil bacterial communities}

Ten environmental variables (i.e., soil moisture, pH, salinity, SOC, LOC, WSOC, SON, LON, WSON, and C/N) explained $23.500 \%$ and $28.000 \%$ of the total changes in the composition of soil bacterial and archaeal communities at the phylum and class levels, respectively (Fig. 6). The results of Monte Carlo permutation tests revealed that the variations at the phylum level were closely related to $\mathrm{C} / \mathrm{N}(F=7.00, p=0.002)$ and WSON $(F=3.10, p=0.036)$ (Fig. $6 a)$, while those at the class level were closely associated with WSOC ( $F$ $=7.10, p=0.002), \mathrm{C} / \mathrm{N}(F=3.70, p=0.010)$, and SON $(F=2.60, p=0.042)$ (Fig. 6b).

The SEM and Pearson's analysis revealed that the absolute abundances of Deltaproteobacteria and Epsilonproteobacteria were significantly positively correlated with soil moisture (Figs. 7 and S3). Soil salinity had a significant negative correlation with the absolute abundance of Betaproteobacteria and a significantly positive correlation with the absolute abundance of Desulfobacterales (Figs. 7 and S3). The absolute abundances of Alteromonadales and Pseudomonadales were significantly positively correlated with SOC concentrations; the absolute abundance of Actinobacteria was significantly negatively correlated with SOC and WSON (Fig. 7 and S3). The absolute abundance of Bacteroidetes was significantly positively correlated with the soil LOC, SON, and C/N (Figs. 7 and S3). A significant negative correlation was found between the absolute abundances of Chlorobi, Ignavibacteria, Chloroflexi, and Chromatiaceae and aboveground biomass (Fig. S3).

\section{Discussion}

Our results showed that coastal embankments caused different responses to soil microbial diversity and community compositions in invasive $S$. alterniflora, as well as native $S$. salsa and $P$. australis salt marshes in the coastal wetlands of eastern China (Fig. 2). The establishment of coastal embankments significantly decreased the Simpson diversity index in the $S$. alterniflora salt marsh, while increasing the OTU richness in the $P$. australis salt marsh (Fig. 2). Interestingly, coastal embankments only slightly changed the microbial diversity and richness in the $0-30 \mathrm{~cm}$ soil layer of the $S$. salsa salt marsh $(p \geq$ 0.05; Fig. 2). Soil nutrient substrates (e.g., SOC and SON) provide media for the growth of microbes and, as such, are critical drivers of soil bacterial and archaeal diversity and richness (Yu et al. 2019; Gao et al. 2020; Novoa et al. 2020; Yang et al. 2020). In this study, the soil bacterial and archaeal diversity were highly positively correlated with SOC, SON, and LON in soil (Fig. S2). The accumulation of nutrients in the soil is primarily determined by the quantity and quality of plant residue input into the soil (Fig. S2; Chantigny 2003; Belay-Tedla et al. 2008; Yang et al. 2016). As the establishment of coastal embankments can limit the growth of S. alterniflora by blocking seawater (Table 1; Fig. S2; Fierer and Jackson, 2006; Zhong et al. 2011; Zhao et al. 2020), the decreased plant biomass led to lower SOC, SON, and LON in the soil of the embanked $S$. alterniflora salt marsh, which ultimately decreased the diversity of the soil bacteria and archaea (Tables 1 and 2; Fig. S2; Yang et al. 2016; Yu et al. 2019). Conversely, the increased biomass of $P$. australis led to the increase of SOC and SON in the embanked $P$. australis salt marsh, which presumptively increased the OTU richness (Tables 1 and 2; Yang et al. 2020). In particular, coastal embankments had insignificant effects on SOC, LOC, WSOC, SON, LON, and WSON in the S. salsa salt 
marsh, which explains the negligible impact of these structures on bacterial and archaeal diversity and richness in the S. salsa salt marsh (Fig. 2 and S2; Table 2). Soil moisture is a vital driver of soil bacterial and archaeal diversity (Guo and Zhou 2020; Yang et al. 2020; Sun et al. 2021). Previous studies have reported that the higher soil water availability in coastal zones is advantageous for the diversity of soil bacteria and archaea of these areas, which is consistent with the results of this study (Table S2; Gao et al. 2020; Novoa et al. 2020). The embankments stop seawater from reaching coastal wetlands, which decreased soil moisture in the $S$. alterniflora salt marsh, contributing to the lower diversity (Table 2). However, the probable presence of aquifers in embanked soil and rains can decrease the impact of embankments (Guo and Jiao 2007; Yang et al. 2016; Ma et al. 2019). In this study, the soil moisture increased in the embanked $P$. australis salt marsh, which might explain its higher OTU richness (Figs. 2 and S2; Table 2). In summary, our results indicated that the establishment of coastal embankments influenced the bacterial and archaeal diversity and richness in $S$. alterniflora and $P$. australis communities by shifting soil nutrient substrates and altering soil moisture (Tables 1 and 2; Fig. S2).

The establishment of coastal embankments drastically modified the composition of soil bacterial and archaeal communities in S. alterniflora and P. australis salt marshes (Fig. 5). PCoA and Bray-Curtis dissimilarity indices revealed that the soil bacterial and archaeal community compositions in the embanked $S$. alterniflora and $P$. australis salt marshes were clustered and distinct from those in unembanked $S$. alterniflora and $P$. australis salt marshes, respectively (Fig. 5). However, the variation in the soil bacterial and archaeal community compositions between the embanked and unembanked $S$. salsa communities was insignificant (Fig. 5). Additionally, SON, which represents available nutrients, vitally influenced the composition of the bacterial and archaeal communities among different plant communities (Figs. 6 and S4; Bates et al. 2011; Yang et al. 2020; Rasmussen et al. 2021). Thus, in this study, the decrease in SON in the S. alterniflora salt marsh following the establishment of coastal embankments caused differentiation of the bacterial and archaeal communities between the unembanked and embanked S. alterniflora salt marshes (Figs. 5, 6, and S4; Table 2). Additionally, the WSOC, which is the immediate energy source for bacteria and archaea, was the most direct driver of soil bacterial and archaeal community composition among different plant communities in the coastal wetlands, because the variations in soil bacterial and archaeal communities were intimately related to the WSOC at the class, order, family, and genus levels (Figs. 6 and S4; Orwin et al. 2016; Santonja et al. 2017; Yang et al. 2020). In this study, the higher concentrations of WSOC and SON in the embanked $P$. australis salt marsh influenced the differentiation of the bacterial and archaeal communities in the embanked and unembanked $P$. australis salt marshes (Figs. 5, 6, and S4; Table 2). Furthermore, the insignificant difference in soil nutrient substrates explained the inconspicuous differentiation of bacterial and archaeal communities between the unembanked and embanked $S$. salsa salt marshes (Figs. 5, 6, and S4; Table 2). Therefore, our results confirmed that the establishment of coastal embankments influences the soil bacterial and archaeal community composition by primarily altering the concentrations of nutrient substrates (Table 2; Liao et al. 2007; Yang et al. 2016).

In this study, the establishment of coastal embankments had a negligible effect on the archaeal relative abundance at the phylum, class, order, family, genus, and species levels (Table S1). As archaea are 
extremophilic microorganisms, few environmental factors can have dramatic effects on their growth, which might explain these results (Bates et al. 2011; Ventosa and Haba 2011).

Some bacterial groups were directly affected by the absence of seawater owing to the coastal embankments. For instance, some classes within Proteobacteria, the most abundant phylum in the sediment along the coast of the Yellow Sea, were strongly impacted (Figs. 3, 4, 7, and S3; Lee et al. 2020; Yang et al. 2020). In this study, the growth of Betaproteobacteria, a dominant class within Proteobacteria, was stimulated in embanked $S$. alterniflora and $P$. australis salt marshes (Figs. 2, 3, and 4; Tables 1 and 2). Additionally, the absolute abundance of Burkholderiales, a dominant order within Betaproteobacteria, increased in embanked $S$. salsa and $P$. australis salt marshes (Figs. 2, 3, and 4; Tables 1 and 2). Baña et al. (2020) reported that members of Betaproteobacteria are rarely found in seawater. Indeed, in this study, the absolute abundance of Betaproteobacteria was negatively correlated with soil salinity (Figs. 7 and S3). Therefore, we speculate that coastal embankments significantly reduced the soil salinity by blocking seawater, which ultimately promoted the growth of members within Betaproteobacteria (Figs. 2, 3, and 4; Tables 1 and 2). Conversely, in this study, the growth of Deltaproteobacteria, also a dominant class within Proteobacteria, was limited in the embanked $S$. alterniflora salt marsh, especially the order Desulfobacterales (Figs. 3, 4, 7, and S3). Many members of Deltaproteobacteria are sulfate-reducing bacteria that usually use sulfate as an electron acceptor (Kuever et al. 2005), and seawater is an important source of sulfate in coastal wetlands (Figs. 7 and S3; Wang et al. 2019a; Zhou et al. 2009; Xia et al. 2015). S. alterniflora is highly capable of accumulating sulfate from seawater, which leads to high sulfur concentrations in the soil through biomass decomposition (Madureira et al. 1997; Otero et al. 2002; Zhou et al. 2009; Xia et al. 2015). Thus, Deltaproteobacteria are common in S. alterniflora salt marshes (Kuever et al. 2005; Wang et al. 2012; Yang et al. 2020). However, in this study, the coastal embankments limited the sulfate input from seawater into the coastal wetlands, which ultimately restricted the growth of Deltaproteobacteria in the embanked S. alterniflora salt marsh (Figs. 3, 4, 7, and S3). Similarly, Epsilonproteobacteria are also involved in sulfur cycling in the coastal wetlands (Zhou et al. 2009; Wang et al. 2012; Yang et al. 2020). In this study, the growth of Epsilonproteobacteria was also restricted in the embanked S. alterniflora salt marsh by the lower the sulfate input (Figs. 3, 4, 7, and S3; Zhou et al. 2009; Wang et al. 2019a; Yang et al. 2020). Moreover, most strains in the order Alteromonadales are aerobic, and coastal embankments could provide an aerobic environment favorable for their growth by decreasing the soil moisture in S. salsa saltmarsh (Table 2; Bowman and McMeekin 2005; Yang et al. 2020). This explains the higher absolute abundance of Alteromonadales in the embanked S. salsa salt marsh (Fig. 3). Shewanella, the most abundant genus in coastal wetlands, grows optimally in seawater media, as it requires sodium ions to grow (Bowman, 2005; Bowman and McMeekin, 2005). In the $P$. australis salt marsh, coastal embankments significantly decreased the soil salinity, which ultimately limited the growth of Shewanella (Fig. 3; Table 2). Therefore, the establishment of coastal embankments strongly influenced the growth of some bacterial strains by stopping seawater from reaching the plant communities and consequently changing the soil physicochemical properties.

The growth of some chemoorganotrophic bacteria, especially oligotrophic and copiotrophic bacteria, was influenced by the establishment of coastal embankments. Actinobacteria is a type of the oligotrophic 
bacteria whose growth is restricted in a nutrient-rich soil environment (Pascault et al. 2013; Trivedi et al. 2013; Verzeaux et al. 2016; Yang et al. 2020). Decreased S. alterniflora biomass in the soil of the embanked salt marsh significantly reduced the availability of nutrients (e.g., SOC and WSON), which was beneficial for the growth of Actinobacteria, reducing its abundance in the embanked $S$. alterniflora sediment (Figs. 3 and S3; Tables 1 and 2). Conversely, Bacteroidetes, the second most abundant bacterial phylum in tidal mudflats and near-shore sediments, is copiotrophic and the accumulation of SON and LOC could enhance its growth (Figs. 7 \& S3; Kim and Kwon 2010). Generally, members of Bacteroidetes are degraders of high-molecular-weight organic matter (Kirchman 2002; Kim and Kwon 2010), and prefer to grow in low-quality media (e.g., those with high $\mathrm{C} / \mathrm{N}$ ), which is consistent with the observations of this study (Figs. 7 and S3; Thomas et al. 2011; Forss et al. 2013; Yang et al. 2020). As such, the abundance of $S$. alterniflora residues could enhance the growth of Bacteroidetes, as these have lignin and lignocellulosic materials and are, therefore, of low quality (Ji et al. 2011; Yang et al. 2020). However, in this study, the concentrations of SON and LOC were lower in the embanked S. alterniflora salt marsh, which supplied less high-molecular-weight organic matter, and limited the growth of Rhodothermi, which is a dominant order within Bacteroidetes (Fig. 4; Table 2). Thus, our results suggest that the establishments of coastal embankments modified distribution of chemoorganotrophic bacteria by altering the concentrations of organic nutrients in the soil (e.g., SOC, SON, LOC, and WSON).

Photosynthetic bacteria are widely distributed in coastal sediments (Okubo et al. 2006; Idi et al. 2014). In this study, the amount of obligately phototrophic bacteria from Chlorobi and the class Chloroflexi (Garrity et al. 2005; Hanada 2014) was significantly higher in the embanked S. alterniflora salt marsh (Fig. 4). The light-limiting effect of the dense vegetation of $S$. alterniflora directly restricts the growth of PSB (He et al. 2012; Li et al. 2014a; Brotosudarmo et al. 2015). Indeed, the absolute abundances of Chlorobi and the class Chloroflexi were significantly negatively correlated with the aboveground biomass of plants (Fig. S3). Thus, the higher occurrence of Chlorobi and the class Chloroflexi might have been caused by the increase in sunlight due to the lower aboveground biomass of plants in the embanked $S$. alterniflora salt marsh (Figs. 4 and S3; Table 1; Wang et al. 2012). In contrast, the dark environment provided by the increased aboveground biomass of plants might explain the lower absolute abundance of 4C0d-2, which are also obligately phototrophic bacteria, in the embanked $P$. australis salt marsh (Fig. 4; Table 1). Chromatiaceae, also known as phototrophic purple sulfur bacteria, are able to grow by photolithoautotrophic metabolism (Imhoff 2005). In this study, the growth of Chromatiaceae was negatively correlated with the aboveground biomass of plants (Fig. S3). Thus, the decrease in the aboveground biomass of $S$. salsa in the embanked salt marsh explained the increased occurrence of Chromatiaceae in this environment (Table 1; Fig. S3). However, Chromatiaceae is also capable of chemoorganoheterotrophic growth under dark eutrophic and anoxic conditions (Imhoff 2005). In the embanked $P$. australis salt marsh, the increased soil moisture and aboveground biomass created an anoxic and dark environment (Tables 1 and 2) which, together with an increased SOC and SON, stimulated the growth of Chromatiaceae (Table 2). Generally, the establishment of coastal embankments affects the growth of PSB by primarily altering the aboveground biomass of plants. 
A wide variety of pathogenic bacteria target plant and animal species; in this study, the presence of coastal embankments stimulated the growth of some pathogenic bacteria (Fig. 3; Dangl and Jones 2001; Glazebrook 2005). Xanthomonadales includes several plant pathogens, especially those belonging to the family Xanthomonadaceae (Bayer-Santos et al. 2019). Xanthomonadales are aerobic and, in this study, their absolute abundance was significantly negatively correlated with soil salinity (Fig. 3; Bayer-Santos et al. 2019). Therefore, the decreased soil moisture and salinity of the embanked S. alterniflora salt marsh created aerobic and low salinity conditions that ultimately promoted the growth of Xanthomonadales, especially that of Xanthomonadaceae (Fig. 3; Table 2; Bayer-Santos et al. 2019). Pseudomonadales is composed of chemoorganotrophic and pathogenic species that affect humans, animals, and plants (Palleroni 2005; Peix et al. 2009). In this study, the absolute abundance of Pseudomonadales was positively correlated with SOC concentration (Figs. 3 and 7; Palleroni 2005; Peix et al. 2009). The increased growth of Pseudomonadales in the embanked $P$. australis salt marsh might be explained by the significant increase in SOC in this environment (Table 2). Therefore, changes in many environmental factors, including the soil nutrient substrates, soil moisture, and salinity following the establishment of coastal embankments might significantly alter the growth of pathogenic bacteria (Figs. 7 and S3; Hutchison et al. 2004; Goberna et al. 2011; Monaghan and Hutchison 2012; Rahube et al. 2014; Shaharoona et al. 2019). Currently, coastal embankments are still being constructed worldwide (Ma et al. 2014). However, potential opportunities and/or threats to soil microbial communities affected by coastal embankments are still poorly understood. This study provides evidence that coastal embankments can significantly modify soil bacterial communities (i.e., diversity and community composition) (Figs. 2, 3, 4, and 5). These changes were due to the significant alteration of soil nutrient substrates quantities (e.g., SOC, SON, and C/N), as well as the dramatic decrease in soil salinity and the change in soil moisture due to lack of seawater in regions with coastal embankments in coastal China (Figs. 6, 7, and S3; Table 2).

\section{Conclusion}

The purpose of this study was to investigate the variations in soil bacterial and archaeal communities following the establishment of coastal embankments, and to identify their driving factors in coastal China. Coastal embankments significantly decreased the bacterial diversity in the $S$. alterniflora salt marsh, while increasing their OTU richness in the $P$. australis salt marsh. Additionally, we found that the embankments modified the soil bacterial and archaeal community compositions in the S. alterniflora and $P$. australis salt marshes. However, the variations in the soil bacterial and archaeal diversity, richness, and community compositions between the embanked and unembanked $S$. salsa salt marshes were insignificant. These results were probably due to the drastic changes in the concentrations of nutrient substrates in the embanked $S$. alterniflora and $P$. australis salt marshes, which were not noted in the $S$. salsa salt marshes.

The coastal embankments had an insignificant effect on the soil archaea, presumably because archaea have a strong tolerance to physically or geochemically extreme conditions. In bacteria, an increased abundance of Betaproteobacteria, which is rare in coastal environments, and a decreased abundance of sulfur- and sodium-dependent bacteria (e.g., Deltaproteobacteria, Epsilonproteobacteria, and Shewanella) 
were observed in the embanked S. alterniflora and $P$. australis salt marshes. The growth of Betaproteobacteria was promoted, while that of Deltaproteobacteria, Epsilonproteobacteria, and Shewanella were limited in embanked environments because the soil physicochemical properties (e.g., soil moisture and salinity) were altered by the lack of seawater in the salt marshes. The coastal embankments reduced plant biomass and the concentrations of SOC, LOC, SON, and LON in the $S$. alterniflora salt marsh, which ultimately decreased the absolute abundance of oligotrophic Rhodothermia (within Bacteroidetes) and increased that of copiotrophic Actinobacteria; the increased plant biomass and concentrations of SOC and SON caused by the coastal embankments stimulated the growth of Pseudomonadales in the embanked $P$. australis salt marsh. An increase in the absolute abundance of PSB (e.g., Chlorobi and Chloroflexi) was observed in the embanked $S$. alterniflora salt marsh, which was attributed to the increase in sunlight due to the decrease of the aboveground biomass of plants. Moreover, the embankments presumably stimulated the growth of some pathogenic bacteria (e.g., Xanthomonadales and Pseudomonadales) in the $S$. alterniflora and $P$. australis salt marshes by modifying the soil physicochemical properties or concentration of nutrient substrates. As the study area is the most important habitat of the endangered Red-crowned Crane, the increased abundance of pathogenic bacteria might damage the local coastal ecosystem.

In summary, this study clarified the effects of coastal embankments on the biogeochemical cycles and highlighted their potential hazards to ecosystems.

\section{Abbreviations}

ANOVA, analysis of variance; ANOSIM, analysis of similarities; C, Carbon; $\mathrm{C} / \mathrm{N}$, Carbon Nitrogen ratio; DNA, Deoxyribonucleic acid; EPA, Embanked Phragmites australis (Cav.) Trin. ex Steud.; ESA, Embanked Spartina alternifolia Loisel.; ESS, Embanked Suaeda salsa (Linn.) Pall.; LDA, Linear discriminant analysis; LEfSe, Linear discriminant analysis effect size; LOC, Labile organic carbon; LON, Labile organic nitrogen; N, Nitrogen; NMDS, Nonmetric multidimensional scaling; OTUs, Operational taxonomic units; PCoA, Principal coordinates analysis; PSB, Photosynthetic bacteria; QIIME, Quantitative insights into microbial ecology; qPCR, Quantitative polymerase chain reaction; RDA, Redundancy analysis; RMSEA, Root-mean-square error of approximation; RNA, Ribonucleic acid; ROC, Recalcitrant organic carbon; RON, Recalcitrant organic nitrogen; SEM, Structural equation modelling; Simpson, Simpson's diversity index; SOC, Soil organic carbon; SON, Soil organic nitrogen; UPA, Unembanked Phragmites australis (Cav.) Trin. ex Steud.; USA, Unembanked Spartina alternifolia Loisel.; USS, Unembanked Suaeda salsa (Linn.) Pall.; WSOC, Water-soluble organic carbon; WSON, Water-soluble organic nitrogen.

\section{Declarations}

Acknowledgements 
We would like to thank Hui Zhao for assistance with the fieldwork, and all of the members of the Dafeng Milu National Nature Reserve and Yancheng National Nature Reserve for supporting this work.

Funding: This work was supported by the National 973 Key Project of Basic Science Research [grant No. 2013CB430405].

Conflicts of interest: The authors declare that they have no known competing financial interests or personal relationships that could have appeared to influence the work reported in this paper.

Availability of data and material: The data that support the findings of this study are available on request from the corresponding author.

Authors' contributions: Hongyu Feng: Conceptualization, Software, Formal analysis, Data Curation, Writing - Original Draft. Yajun Qiao: Methodology, Investigation. Lu Xia: Conceptualization, Methodology, Software, Formal analysis, Data Curation, Writing - Original Draft, Writing - Review \& Editing, Visualization. Wen Yang: Conceptualization, Methodology, Writing - Review \& Editing, Project administration, Funding acquisition. Yongqiang Zhao: Resources, Investigation. Nasreen Jeelani: Writing - Review \& Editing. Shuqing An: Conceptualization, Resources, Writing - Review \& Editing, Project administration, Funding acquisition.

Code availability: Not applicable.

Ethics approval: Not applicable.

Consent to participate: All authors participated in this manuscript.

Consent for publication: All authors revised the manuscript critically and approved the final manuscript for publication.

\section{References}

1. Angel R, Soares MI, Ungar ED, Gillor O (2010) Biogeography of soil archaea and bacteria along a steep precipitation gradient. The ISME Journal 4:553-563

2. An SQ, Gu BH, Zhou CF, Wang ZS, Deng ZF, Zhi YB, Li HL, Chen L, Yu DH, Liu YH (2007) Spartina invasion in China: implications for invasive species management and future research. Weed Res 47:183-191

3. Bai J, Xiao R, Zhang K, Gao H, Cui B, Liu X (2013) Soil organic carbon as affected by land use in young and old reclaimed regions of a coastal estuary wetland, China. Soil Use Manag 29:57-64

4. Bainard LD, Hamel C, Gan YT (2016) Edaphic properties override the influence of crops on the composition of the soil bacterial community in a semiarid agroecosystem. Appl Soil Ecol 105:160168 
5. Baña Z, Abad N, Uranga A, Azúa I, Artolozaga I, Unanue M, Iriberri J, Arrieta JM, Ayo B (2020) Recurrent seasonal changes in bacterial growth efficiency, metabolism and community composition in coastal waters. Environ Microbiol 22:369-380

6. Bates ST, Berg-Lyons DB, Caporaso JG, Walters WA, Knight R, Fierer N (2011) Examining the global distribution of dominant archaeal populations in soil. The ISME Journal 5:908-917

7. Bayer-Santos E, Ceseti LD, Farah CS, Alvarez-Martinez CE (2019) Distribution, function and regulation of type 6 secretion systems of Xanthomonadales. Front Microbiol 10:1635

8. Bokulich NA, Subramanian S, Faith JJ, Gevers D, Gordon JI, Knight R, Mills DA, Caporaso JG (2013) Quality-filtering vastly improves diversity estimates from Illumina amplicon sequencing. Nature methods 10:57-59

9. Boldea O, Magnus JR (2009) Maximum likelihood estimation of the multivariate normal mixture model. J Am Stat Assoc 104:1539-1549

10. Bowman JP (2005) Genus XIII. Shewanella. In: Brenner, D.J., Krieg, N.R., Staley, J.T., Garrity, G.M. (eds) Bergey's manual of systematic bacteriology, vol 2, 2nd edn, The proteobacteria, Part B. The gammaproteobacteria. Springer, New York, pp 480

11. Bowman JP, McMeekin TA (2005) Order X. Alteromonadalesord. nov. In: Brenner, D.J., Krieg, N.R., Staley, J.T., Garrity, G.M. (eds) Bergey's manual of systematic bacteriology, vol 2, 2nd edn, The proteobacteria, Part B. The gammaproteobacteria. Springer, New York, pp 443

12. Brotosudarmo THP, Limantara L, Heriyanto, Prihastyanti MNU (2015) Adaptation of the photosynthetic unit of purple bacteria to changes of light illumination intensities. Procedia Chem 14:414-421

13. Buckley D, Schmidt T (2002) Exploring the biodiversity of soil - a microbial rain forest. In: Staley J, Reysenbach A (eds) Biodiversity of microbial life. John Wiley \& Sons, New York, pp 183-208

14. Bu NS, Qu JF, Li G, Zhao B, Zhang RJ, Fang CM (2015) Reclamation of coastal salt marshes promoted carbon loss form previously-sequestered soil carbon pool. Ecol Eng 81:335-339

15. Cabrera ML, Beare MH (1993) Alkaline persulfate oxidation for determining total nitrogen in microbial biomass extracts. Soil Sci Soc Am J 57:1007-1012

16. Caporaso JG, Kuczynski J, Stombaugh J, Bittinger K, Bushman FD, Costello EK, Fierer N, Pena AG, Goodrich JK, Gordon JI, Huttley GA, Kelley ST, Knights D, Koenig JE, Ley RE, Lozupone CA, McDonald D, Muegge BD, Pirrung M, Reeder J, Sevinsky JR, Tumbaugh PJ, Walters WA, Widmann J, Yatsunenko T, Zaneveld J, Knight R (2010) QIIME allows analysis of high-throughput community sequencing data. Nature methods 7:335-336

17. Chung CH, Zhuo RZ, Xu GW (2004) Creation of Spartina plantations for reclaiming Dongtai, China, tidal flats and offshore sands. Ecological Engineer 23:135-150

18. Cui J, Liu C, Li ZL, Wang L, Chen XF, Ye ZZ, Fang CM (2012) Long-term changes in topsoil chemical properties under centuries of cultivation after reclamation of coastal wetlands in the Yangtze Estuary, China. Soil Tillage Research 123:50-60 
19. Dangl JL, Jones JDG (2001) Plant pathogens and integrated defence responses to infection. Nature 411:826-833

20. DeCrappeo NM, DeLorenze EJ, Giguere AT, Pyke DA, Bottomley PJ (2017) Fungal and bacterial contributions to nitrogen cycling in cheatgrass-invaded and uninvaded native sagebrush soils of the western USA. Plant Soil 416:271-281

21. Dick TM, Osunkoya $O 0$ (2000) Influence of tidal restriction floodgates on decomposition of mangrove litter. Aquat Bot 68:273-280

22. Edgar RC (2004) MUSCLE: multiple sequence alignment with high accuracy and high throughput. Nucleic acids research 32:1792-1797

23. Edgar RC (2013) UPARSE: highly accurate OTU sequences from microbial amplicon reads. Nature methods 10:996-998

24. Edgar RC, Haas BJ, Clemente JC, Quince C, Knight R (2011) UCHIME improves sensitivity and speed of chimera detection. Bioinformatics 27:2194-2200

25. Fierer N, Breitbart M, Nulton J, Salamon P, Lozupone C, Jones R, Robeson M, Edwards RA, Felts B, Rayhawk S, Knight R, Rohwer F, Jackson RB (2007) Metagenomic and small-subunit rRNA analyses reveal the genetic diversity of bacteria, archaea, fungi and viruses in soil. Appl Environ Microbiol 73:7059-7066

26. Fierer N, Jackson JA, Vilgalys R, Jackson RB (2005) Assessment of soil microbial community structure by use of taxonspecific quantitative PCR assays. Appl Environ Microbiol 71:4117-4120

27. Fierer N, Jackson RB (2006) The diversity and biogeography of soil bacterial communities. Proc Natl Acad Sci USA 103:626-631

28. Forss J, Pinhassi J, Lindh M, Welander U (2013) Microbial diversity in a continuous system based on rice husks for biodegradation of the azo dyes reactive red 2 and reactive black 5 . Biores Technol 130:681-688

29. Gao GF, Peng D, Zhang YH, Li YT, Fan KK, Tripathi BM, Adams JM, Chu HY (2020) Dramatic change of bacterial assembly process and co-occurrence pattern in Spartina alterniflora salt marsh along an inundation frequency gradient. Science of the Total Environment, 142546

30. Garrity GM, Bell JA, Lilburn T (2005) The Revised Road Map to the Manual In: Brenner, D.J., Krieg, N.R., Staley, J.T., Garrity, G.M. (eds) Bergey's manual of systematic bacteriology, vol 2, 2nd edn, The proteobacteria, Part A. Introductory essays. Springer, New York, pp 169

31. Glazebrook J (2005) Contrasting mechanisms of defense against biotrophic and necrotrophic pathogens. Annual Review of Phytopathology 43:205-227

32. Goberna M, Podmirseg SM, Waldhuber S, Knapp BA, García C, Insam H (2011) Pathogenic bacteria and mineral $\mathrm{N}$ in soils following the land spreading of biogas digestates and fresh manure. Appl Soil Ecol 49:18-25

33. Gryta A, Frac M (2020) Methodological aspects of multiplex terminal restriction fragment length polymorphism-technique to describe the genetic diversity of soil bacteria, archaea and fungi. Sensors 20:3292 
34. Guo HP, Jiao JJ (2007) Impact of coastal land reclamation on ground water level and the sea water interface. Ground Water 45:362-367

35. Guo XL, Zhou YB (2020) Effects of land use patterns on the bacterial community structure and diversity of wetland soil in the Sanjiang Plain. Journal of Soil Science Plant Nutrition 21:1-12

36. Haas BJ, Gevers D, Earl AM, Feldgarden M, Ward DV, Giannoukos G, Ciulla D, Tabbaa D, Highlander SK, Sodergren E, Methe B, DeSantis TZ, Petrosino JF, Knight R, Birren BW (2011) Chimeric 16S rRNA sequence formation and detection in Sanger and 454-pyrosequenced PCR amplicons. Genome research 21:494-504

37. Hanada S (2014) The phylum Chloroflexi, the family Chloroflexaceae, and the related phototrophic families Oscillochloridaceae and Roseiflexaceaeln. In: Rosenberg E, DeLong EF, Lory S, Stackebrandt E, Thompson F (eds) The Prokaryotes, Other major lineages of bacteria and the archaea. Springer, Berlin Heidelberg, pp 515-529

38. He Q, Cui B, An Y (2012) Physical stress, not biotic interactions, preclude an invasive grass from establishing in forb-dominated salt marshes. PLoS ONE 7:e33164

39. Högberg MN, Högberg P, Myrold DD (2007) Is microbial community composition in boreal forest soils determined by $\mathrm{pH}, \mathrm{C}$-to-N ratio, the trees, or all three? Oecologia 150:590-601

40. Hutchison ML, Walters LD, Moore A, Crookes KM, Avery SM (2004) Effect of length of time before incorporation on survival of pathogenic bacteria present in livestock wastes applied to agricultural soil. Appl Environ Microbiol 70:5111-5118

41. Idi A, Nor MHM, Wahab MFA, Ibrahim Z (2014) Photosynthetic bacteria: an eco-friendly and cheap tool for bioremediation. Reviews in Environmental Science Bio-Technology 14:271-285

42. Imhoff JF (2005) Family I. Bavendamm. In: Brenner, D.J., Krieg, N.R., Staley, J.T., Garrity, G.M. (eds) Bergey's manual of systematic bacteriology, vol 2, 2nd edn, The proteobacteria, Part B. The gammaproteobacteria. Springer, New York, pp 3

43. Ji YF, Wu BL, Ding YH, Qin P (2011) Nutritional components of Phragmites australis and Spartina alterniflora in Dafeng free-range David's Deer habitat of Jiangsu Province, East China: a comparative analysis. Chin J Ecol 30:2240-2244

44. Kim SJ, Kwon KK (2010) Bacteroidetes. In: Timmis KN (ed) Handbook of hydrocarbon and lipid microbiology, The Actinobacteria. Springer, Berlin, p 1813

45. Kirchman DL (2002) The ecology of Cytophaga - Flavobacteria in aquatic environments. FEMS Microbiological Ecology 39:91-100

46. Kuang SP, Dong ZW, Wang BC, Wang HH, Li JL, Shao HB (2021) Changes of sensitive microbial community in oil polluted soil in the coastal area in Shandong, China for ecorestoration. Ecotoxicol Environ Saf 207:111551

47. Kuever J, Rainey FA, Widdel F (2005) Order III. Desulfobacteralesord. nov. In: Brenner, D.J., Krieg, N.R., Staley, J.T., Garrity, G.M. (eds) Bergey's manual of systematic bacteriology, vol 2, 2nd edn, The proteobacteria, Part C. The alpha-, beta-, delta-, and epsilonproteobacteria. Springer, New York, pp 959 
48. Kuske CR, Ticknor LO, Miller ME, Dunbar JM, Davis JA, Barns SM, Belnap J (2002) Comparison of soil bacterial communities in rhizospheres of three plant species and the interspaces in an arid grassland. Appl Environ Microbiol 68:1854-1863

49. Laudicina VA, Hurtado MD, Badalucco L, Delgado A, Palazzolo E, Panno M (2009) Soil chemical and biochemical properties of a salt-marsh alluvial Spanish area after long-term reclamation. Biology Fertility of Soil 45:691-700

50. Lee H, Heo YM, Kwon SL, Yoo Y, Lee AH, Kwon BO, Kim GH, Kim KJS, J.J (2020) Recovery of the benthic bacterial community in coastal abandoned saltern required over 35 years: a comparative case study in the Yellow Sea. Environ Int 135:105412

51. Liao CZ, Luo YQ, Jiang LF, Zhou XH, Wu XW, Fang CM, Chen JQ, Li B (2007) Invasion of Spartina alterniflora enhanced ecosystem carbon and nitrogen stocks in the Yangtze estuary. China Ecosystems 10:1351-1361

52. Li DL, Ding YQ, Yuan Y, Lloyd H, Zhang ZW (2014b) Female tidal mudflat crabs represent a critical food resource for migratory red-crowned cranes in the Yellow River Delta, China. Bird Conservation International 24:416-428

53. Liu CY, Jiang HX, Hou YQ, Zhang SQ, Su LY, Li XF, Pan X, Wen ZF (2010) Habitat changes for breeding waterbirds in Yancheng national reserve, China: a remote sensing study. Wetlands 30:879888

54. Liu CY, Jiang HX, Zhang SQ, Li CR, Hou YQ, Qian FW (2013) Multi-scale analysis to uncover habitat use of red-crowned cranes: implication for conservation. Current Zoology 59:604-617

55. Liu MY (2018) Remote sensing analysis of Spartina alterniflora in the coastal areas of China during 1990 to 2015 [D]. Changchun: University of Chinese Academy of Sciences (Northeast Institute of Geography and Agroecology, Chinese Academy of Sciences)

56. Li XB, Kang YH, Wang XM (2019) Response of soil properties and vegetation to reclamation period using drip irrigation in coastal saline soils of the Bohai Gulf. Paddy Water Environ 17:803-812

57. Li ZJ, Wang WQ, Zhang YH (2014a) Recruitment and herbivory affect spread of invasive Spartina alterniflora in China. Ecology 95:1972-1980

58. Madureira MJ, Vale C, Goncalves MLS (1997) Effect of plants on sulphur geochemistry in the tagus salt-marshes sediments. Mar Chem 58:27-37

59. Magoč T, Salzberg SL (2011) Flash: fast length adjustment of short reads to improve genome assemblies. Bioinformatics 27:2957-2963

60. Ma TT, Li XW, Bai JH, Cui BS (2019) Impacts of coastal reclamation on natural wetlands in large river deltas in China. Chin Geogra Sci 29:640-651

61. Ma ZJ, Melville DS, Liu JG, Chen Y, Yang HY, Ren WW, Zhang ZW, Piersma T, Li B (2014) Ecosystems management rethinking China's new great wall. Science 346:912-914

62. Monaghan JM, Hutchison ML (2012) Distribution and decline of human pathogenic bacteria in soil after application in irrigation water and the potential for soil-splash-mediated dispersal onto fresh produce. J Appl Microbiol 112:1007-1019

Page 21/32 
63. Nannipieri P, Ascher J, Ceccherini MT, Landi L, Pietramellara G, Renella G (2003) Microbial diversity and soil functions. Eur J Soil Sci 54:655-670

64. Newton RJ, McMahon KD (2011) Seasonal differences in bacterial community composition following nutrient additions in a eutrophic lake. Environ Microbiol 13:887-899

65. Nguyen LTT, Osanai Y, Lai K, Anderson IC, Bange MP, Tissue DT, Singh BK (2018) Responses of the soil microbial community to nitrogen fertilizer regimes and historical exposure to extreme weather events: flooding or prolonged-drought. Soil Biol Biochem 118:227-236

66. Novoa A, Keet JH, Lechuga-Lago Y, Pyšek P, Roux JJL (2020) Urbanization and Carpobrotus edulis invasion alter the diversity and composition of soil bacterial communities in coastal areas. FEMS Microbiol Ecol 96:1-12

67. Okubo Y, Futamata $\mathrm{H}$, Hiraishi A (2006) Characterization of phototrophic purple nonsulfur bacteria forming colored microbial mats in a swine wastewater ditch. Appl Environ Microbiol 72:6225-6233

68. Orwin KH, Dickie IA, Wood JR, Bonner KI, Holdaway RJ (2016) Soil microbial community structure explains the resistance of respiration to a dry-rewet cycle, but not soil functioning under static conditions. Funct Ecol 30:1430-1439

69. Otero XL, Macias F (2002) Variation with depth and season in metal sulfides in salt marsh soils. Biogeochemistry 61:247-268

70. Palleroni NJ (2005) Genus I. Pseudomonas Migula1894, $237^{A L}$ (Nom. Cons., Opin. 5 of the Jud. Comm. 1952, 121). In: Brenner, D.J., Krieg, N.R., Staley, J.T., Garrity, G.M. (eds) Bergey's manual of systematic bacteriology, vol 2, 2nd edn, The proteobacteria, Part B. The gammaproteobacteria. Springer, New York, pp 323

71. Pascault N, Ranjard L, Kaisermann A, Bachar D, Christen R, Terrat S, Mathieu O, Leveque J, Mougel C, Henault C, Lemanceau P, Pean M, Boiry S, Fontaine S, Maron PA (2013) Stimulation of different functional groups of bacteria by various plant residues as a driver of soil priming effect. Ecosystem 16:810-822

72. Peix A, Ramirez-Bahena MH, Velázquez E (2009) Historical evolution and current status of the taxonomy of genus Pseudomonas. Infection Genetics Evolution 9:1132-1147

73. Peralta RM, Ahn C, Gillevet PM (2013) Characterization of soil bacterial community structure and physicochenmical properties in created and natural wetlands. Sci Total Environ 443:725-732

74. Philippot L, Raaijmakers JM, Lemanceau P, van der Putten WH (2013) Going back to the roots: the microbial ecology of the rhizosphere. Nat Rev Microbiol 11:789-799

75. Podosokorskaya OA, Bonch-Osmolovskaya EA, Novikov AA, Kolganova TV, Kublanov IV (2013) Ornatilineaapprima gen. Nov, sp. Nov., a cellulolytic representative of the class Anaerolineae. International Journal of System Evolution Microbial 63:86-92

76. Qin P, Li SY (2012) Positive and negative effects of the non-native plant, Spartina alterniflora and its ecological control. Journal of Biosafety 21:167-176 
77. Quast C, Pruesse E, Yilmaz P, Gerken J, Schweer T, Yarza P, Peplies J, Glockner FO (2013) The SILVA ribosomal RNA gene database project: improved data processing and web-based tools. Nucleic Acids Res 41:D590-D596

78. Rahube TO, Marti R, Scott A, Tien YC, Murray R, Sabourin L, Zhang Y, Duenk P, Lapen DR, Topp E (2014) Impact of fertilizing with raw or anaerobically digested sewage sludge on the abundance of antibiotic-resistant coliforms, antibiotic resistance genes, and pathogenic bacteria in soil and on vegetables at harvest. Appl Environ Microbiol 80:6898-6907

79. Rasmussen AN, Damashek J, Eloe-Fadrosh EA, Francis CA (2021) In-depth spatiotemporal characterization of planktonic archaeal and bacterial communities in North and South San Francisco Bay. Microb Ecol 81:601-616

80. Rath KM, Rousk J (2015) Salt effects on the soil microbial decomposer community and their role in organic carbon cycling: a review. Soil Biol Biochem 81:108-123

81. Rovira P, Vallejo VR (2002) Labile and recalcitrant pools of carbon and nitrogen inorganic matter decomposing at different depths in soil: an acid hydrolysis approach. Geoderma 107:109-141

82. Santonja M, Fernandez C, Proffit M, Gers C, Gauquelin T, Reiter IM, Cramer W, Baldy V (2017) Plant litter mixture partly mitigates the negative effects of extended drought on soil biota and litter decomposition in a Mediterranean oak forest. J Ecol 105:801-815

83. Schermelleh-Engel K, Moosbrugger H, Müller H (2003) Evaluating the fit of structural equation models: tests of significance and descriptive goodness-of - fit measures. Method Psychology Research 8:23-74

84. Segata N, Izard J, Waldron L, Gevers D, Miropolsky L, Garrett WS, Huttenhower C (2011) Metagenomic biomarker discovery and explanation. Genome Biol 12:R60

85. Shaharoona B, Al-Ismaily S, Al-Mayahi A, Al-Harrasi N, Al-Kindi R, Al-Sulaimi A, Al-Busaidi H, Al-Abri M (2019) The role of urbanization in soil and groundwater contamination by heavy metals and pathogenic bacteria: a case study from Oman. Heliyon 5:e01771

86. Sun ML, Li T, Li DM, Zhao YL, Gao FM, Sun LF, Li X (2021) Conversion of land use from upland to paddy field changes soil bacterial community structure in Mollisols of Northeast China. Microb Ecol 81:1018-1028

87. Sun RB, Zhang XX, Guo XS, Wang DZ, Chu HY (2015) Bacterial diversity in soils subjected to longterm chemical fertilization can be more stably maintained with the addition of livestock manure than wheat straw. Soil Biol Biochem 88:9-18

88. Thomas F, Hehemann JH, Rebuffet E, Czjzk M, Michel G (2011) Environmental and gut Bacteroidetes: the food connection. Frontier in Microbiology 2:2-16

89. Trivedi P, Anderson IC, Singh BK (2013) Microbial modulators of soil carbon storage: integrating genomic and metabolic knowledge for global prediction. Trends Microbiol 21:641-651

90. Urbanová M, Snajdr J, Baldrian P (2015) Composition of fungal and bacterial communities in forest litter and soil is largely determined by dominant trees. Soil Biol Biochem 84:53-64 
91. Verzeaux J, Alahmad A, Habbib H, Nivelle E, Roger D, Lacoux J, Decocq G, Hirel B, Catterou M, Spicher F, Dubois F, Duclercq J, Tetu T (2016) Cover crops prevent the deleterious effect of nitrogen fertilization on bacterial diversity by maintaining the carbon content of ploughed soil. Geoderma 281:49-57

92. Ventosa A, Haba RRDL (2011) Archea. In: Gargaud M, Amils R, Quintanilla C, Cleaves J, Irvine HJ, Pinti WM, Viso D, M. (eds) Encyclopedia of astrobiology. Springer, New York, p 57

93. Wang DD, Gao S, Du YF, Gao WH (2012) Distribution patterns of sediment chlorophyll-a in Spartina alterniflora salt marshes at Rudong coast of Jiangsu, East China. Chinese Journal of Ecology $31: 2247-2254$

94. Wang J, Liu HY, Li YF, Liu L, Xie FF, Lou CR, Zhang HB (2019b) Effects of Spartina alterniflora invasion on quality of the red-crowned crane (Grus japonensis) wintering habitat. Environ Sci Pollut Res 26:21546-21555

95. Wang JL, Liu ZQ (2005) Protection and sustainable utilization for the biodiversity of Yancheng seashore. Chin J Ecol 24:1090-1094

96. Wang XH, Yang JH, Xie XF, Chen XJ, Pu LJ, Zhang XW (2020a) Soil microbial succession with soil development since coastal reclamation. Catena 187:104393

97. Wang YD, Wang ZL, Feng XP, Guo CC, Chen Q (2014) Long-term effect of agricultural reclamation on soil chemical properties of a coastal saline marsh in Bohai Rim, Northern China. PloS One 9:e93727

98. Wang Z, Li N, Gao S, An SQ (2020b) Response of wintering waterbird diversity to reclamation history and post-reclamation habitat along Yellow Sea coast. Integr Zool 15:595-602

99. Wang ZY, Zhang HY, He CQ, Liu C, Liang X, Chen XP (2019a) Spatiotemporal variability in soil sulfur storage is changed by exotic Spartina alterniflora in the Jiuduansha wetland, China. Ecol Eng 133:160-166

100. Xia L, Yang W, Zhao H, An SQ (2015) High soil sulfur promotes invasion of exotic Spartina alterniflora into native Phragmites australis Marsh. Clean Soil Air Water 43:1666-1671

101. Xie ZF, Wang ZW, Wang QY, Zhu CW, Wu ZC (2014) An anaerobic dynamic membrane bioreactor (AnDMBR) for landfill leachate treatment: performance and microbial community identification. Biores Technol 161:29-39

102. Xu SQ, Wang YD, Guo CC, Zhang ZG, Shang YT, Chen Q, Wang ZL (2017) Comparison of microbial community composition and diversity in native coastal wetlands and wetlands that have undergone long-term agricultural reclamation. Wetlands 37:99-108

103. Yang W, Cai AD, Wang JS, Luo YQ, Cheng XL, An SQ (2020) Exotic Spartina alterniflora Loisel. invasion significantly shifts soil bacterial communities with the successional gradient of saltmarsh in eastern China. Plant Soil 449:97-115

104. Yang W, Li N, Leng X, Qiao YJ, Cheng XL, An SQ (2016) The impact of sea embankment on soil organic carbon and nitrogen pools in invasive Spartina alterniflora and native Suaeda salsa saltmarshes in eastern China. Ecol Eng 97:582-592 
105. Yang W, Xia L, Zhu ZH, Jiang LF, Cheng XL, An SQ (2019) Shift in soil organic carbon and nitrogen pools in different reclaimed lands following intensive coastal reclamation on the coasts of eastern China. Sci Rep 9:5921

106. Yu HL, Ling N, Wang TT, Zhu C, Wang Y, Wang SJ, Gao Q (2019) Responses of soil biological trains and bacterial communities to nitrogen fertilization mediate maize yields across three soil types. Soil Tillage Res 185:61-69

107. Yu ZS, Northup RR, Dahlgren RA (1994) Determination of dissolved organic nitrogen using persulfate oxidation and conductimetric quantification of nitrate-nitrogen. Commun Soil Sci Plant Anal 25:3161-3169

108. Zechmeister-Boltenstern S, Keiblinger KM, Mooshammer M, Penuelas J, Richter A, Sardans J, Wanek W (2015) The application of ecological stoichiometry to plant-microbial-soil organic matter transformations. Ecol Monogr 85:133-155

109. Zhang GL, Bai JH, Tebbe CC, Zhao QQ, Jia J, Wang W, Wang X, Yu L (2021) Salinity controls soil microbial community structure and function in coastal estuarine wetlands. Environ Microbiol 23:1020-1037

110. Zhao QQ, Zhao HX, Gao YC, Zheng LW, Wang JN, Bai JH (2020) Alterations of bacterial and archaeal communities by freshwater input in coastal wetlands of the Yellow River Delta, China. Applied Soil Ecology, 103581

111. Zhong CQ, Wang JX, Qin P (2011) Relationship of salt marsh plant distribution and soil physical and chemical characteristic in coastal saltmarsh plant of north Jiangsu Province. Transactions of Oceanology Limnology 4:151-157

112. Zhou CF, An SQ, Deng ZF, Yin DQ, Zhi YB, Sun ZY, Zhao H, Zhou LX, Fang C, Chen Q (2009) Sulfur storage changed by exotic Spartina alterniflora in coastal saltmarshes of China. Ecol Eng 35:536543

\section{Figures}




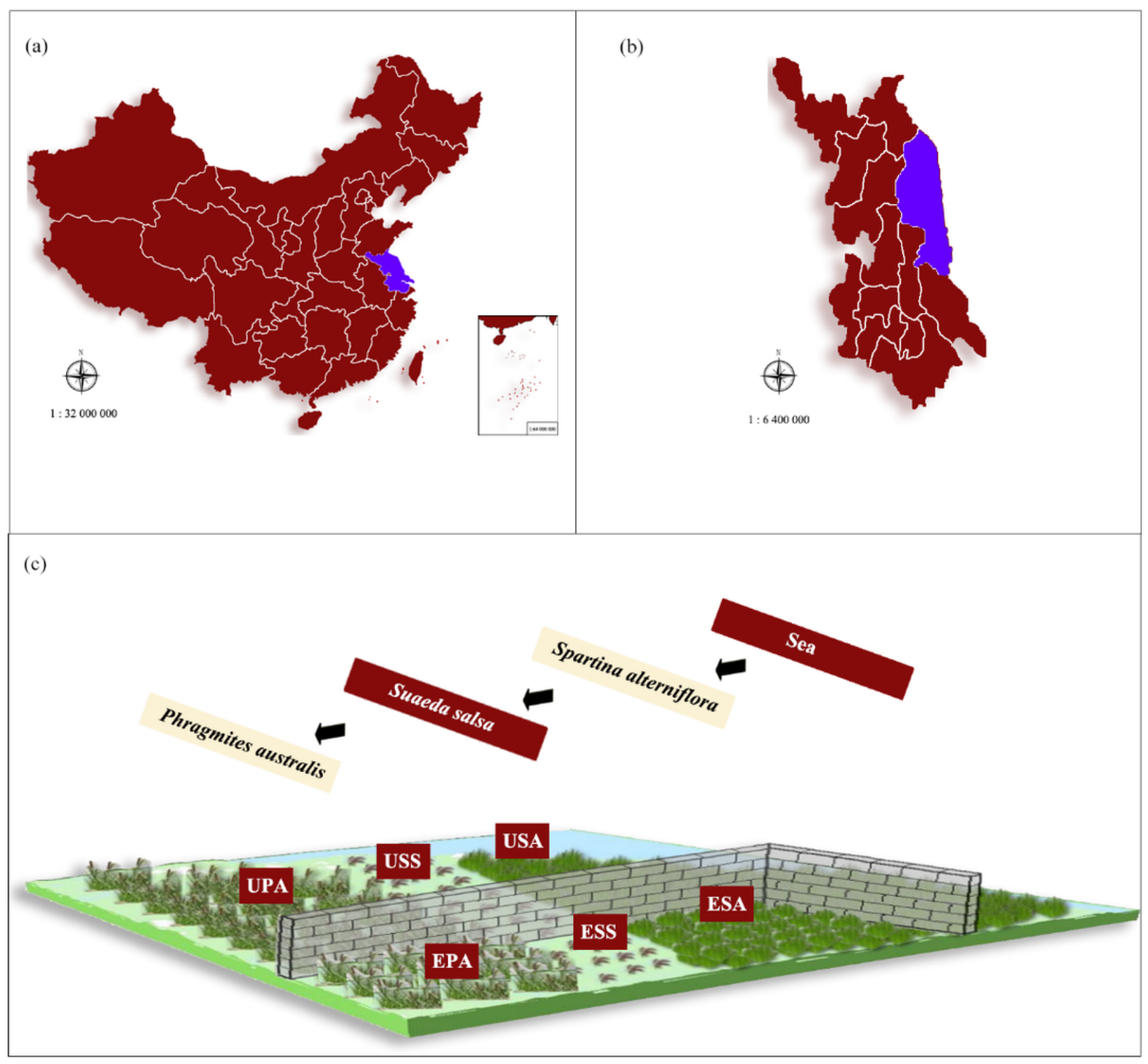

Figure 1

Location of the sampling site in Yancheng, Jiangsu, China. USA: unembanked Spartina alterniflora salt marsh; ESA: embanked S. alterniflora salt marsh; USS: unembanked Suaeda salsa salt marsh; ESS: embanked S. salsa salt marsh; UPA: unembanked Phragmites australis salt marsh; EPA: embanked P. australis salt marsh. 
(a) OTU Richness

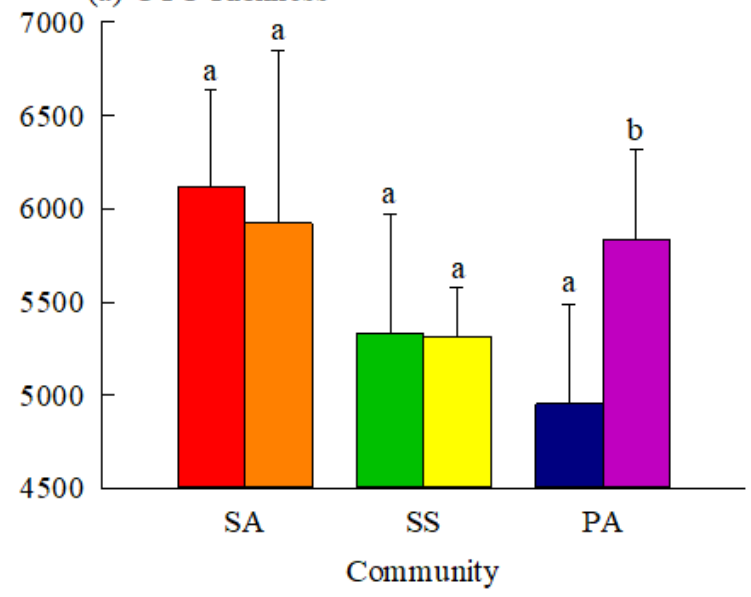

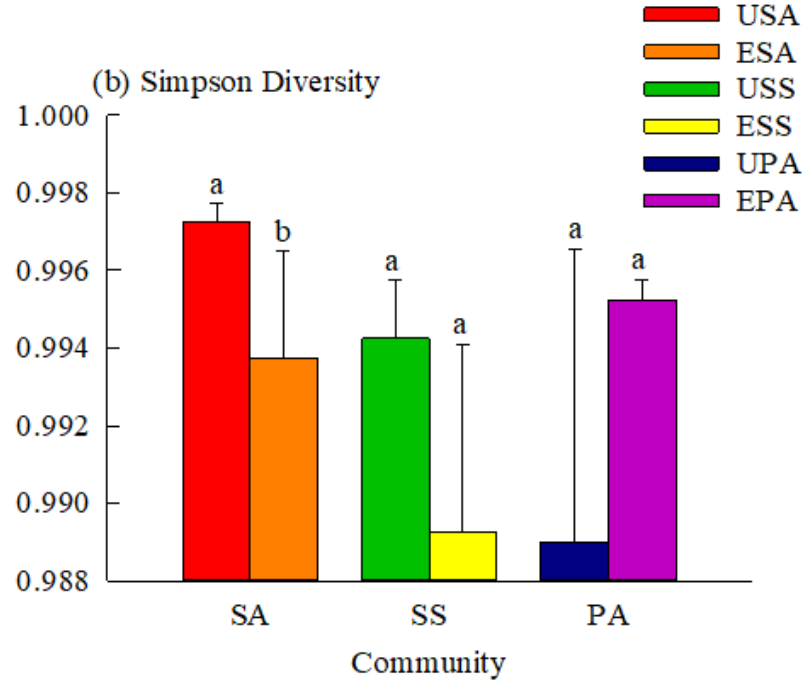

\section{Figure 2}

The OTU richness (a) and the Simpson diversity (b) in the unembanked and embanked Spartina alterniflora, Suaeda salsa, and Phragmites australis salt marshes $(0-30 \mathrm{~cm}$ soil depth). SA: S. alterniflora; SS: S. salsa; PA: P. australis; USA = unembanked SA salt marsh; ESA = embanked SA salt marsh; USS = unembanked SS salt marsh; ESS = embanked SS salt marsh; UPA = unembanked PA salt marsh; EPA = embanked PA salt marsh. 
(a)



(b)

Gammaproteobacteria

Chromatiaceae Alteromonadales

Burkholderiales
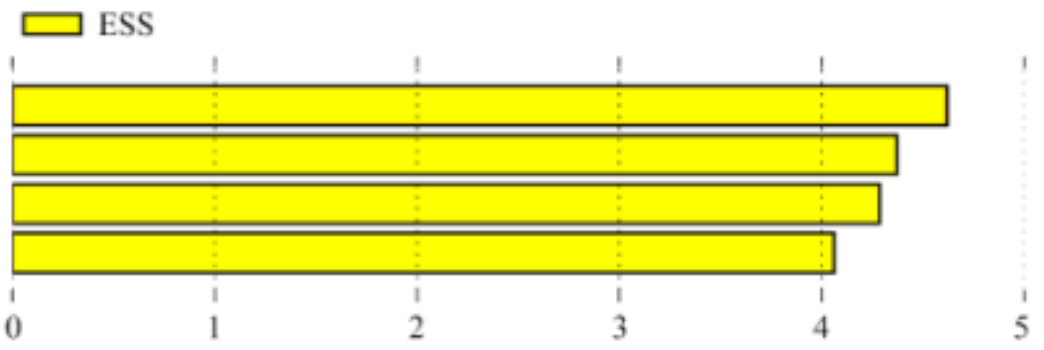

LDA SCORE (log 10)

(c)

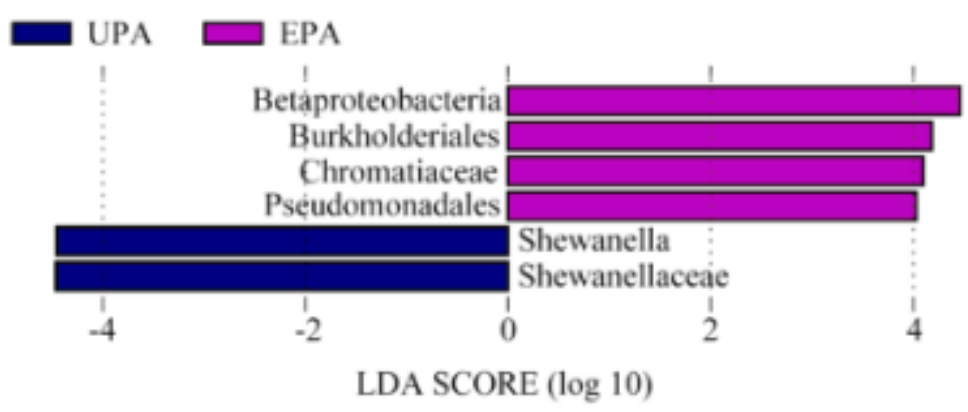

\section{Figure 3}

Indicator bacterial and archaeal groups between the unembanked and embanked (a) Spartina alterniflora, (b) Suaeda salsa, and (c) Phragmites australis salt marshes with LDA $>4$. 


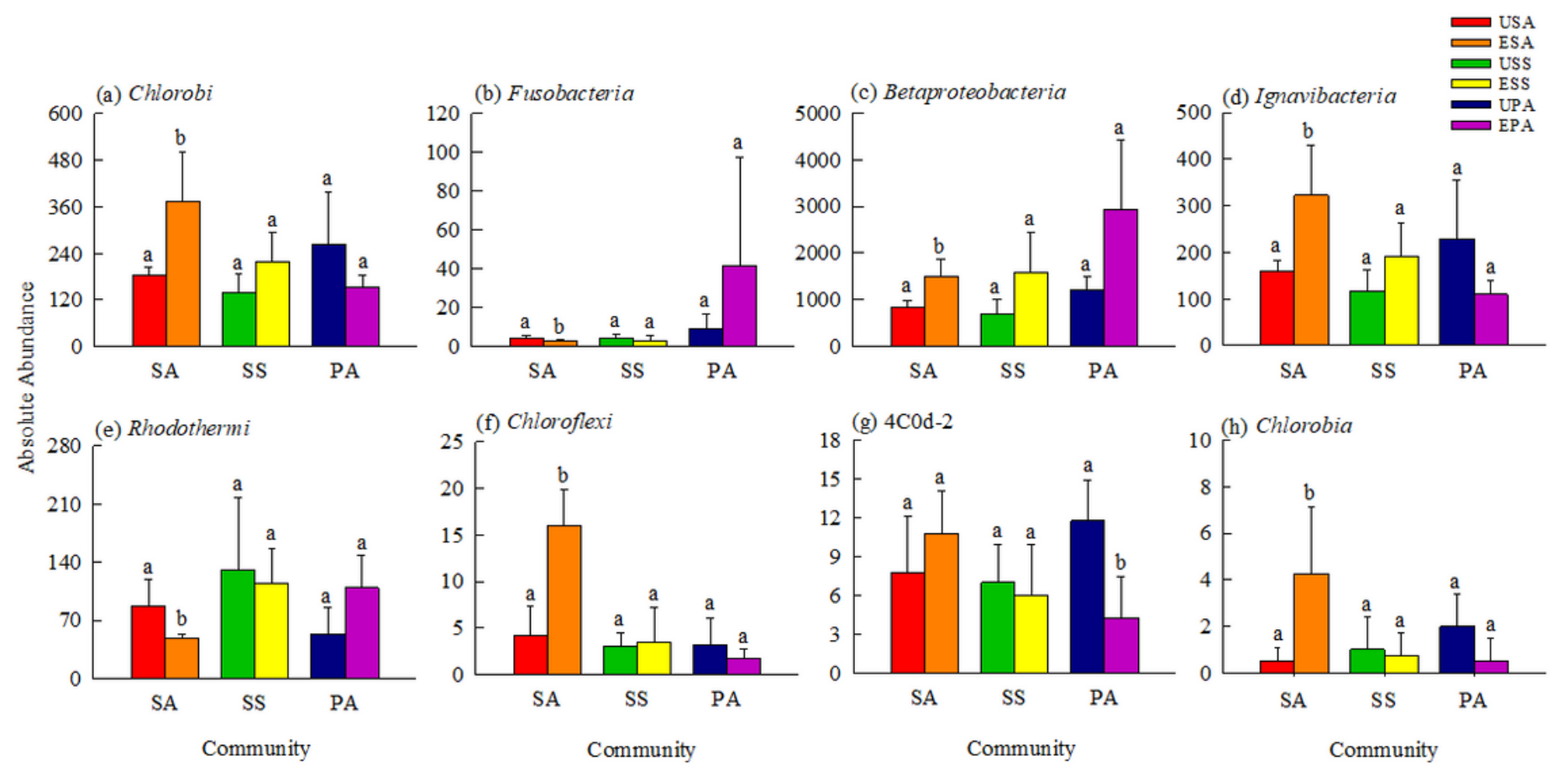

Figure 4

The absolute abundance of dominant bacteria in the unembanked and embanked Spartina alterniflora, Suaeda salsa, and Phragmites australis salt marshes. Different superscripted lower-case letters indicate $p<0.05$ between the unembanked and embanked ranges in the same plant community. 
PCoA
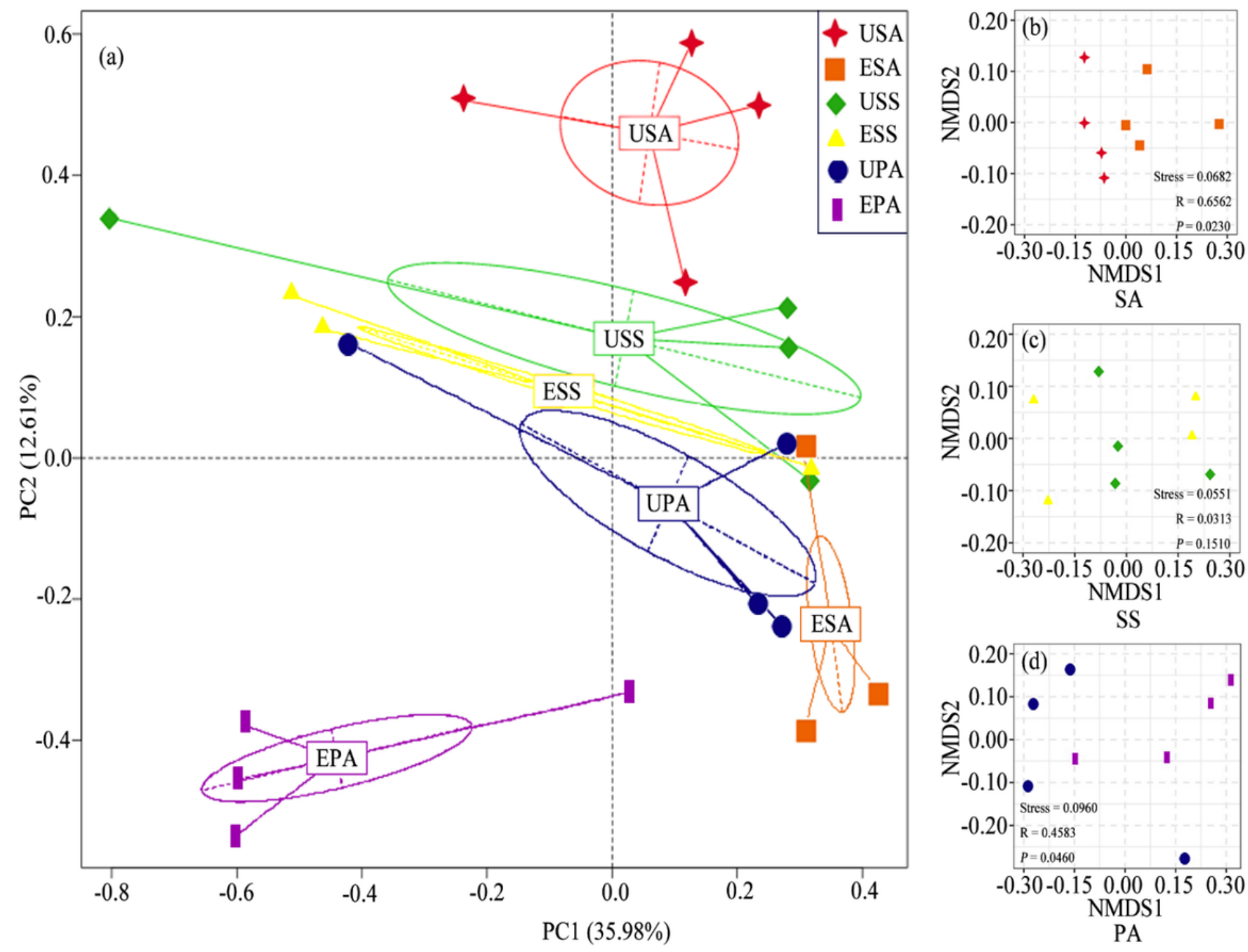

Figure 5

Principal coordinates analysis (PCoA) (a), and nonmetric multidimensional scaling (NMDS) plot of bacterial Bray-Curtis dissimilarity between the unembanked and embanked SA (b), SS (c), and PA(d) salt marshes. Red stars represent USA, orange squares represent ESA, green diamonds represent USS, yellow triangles represent ESS, blue circles represent UPA, and purple rectangles represent EPA. 
(a)

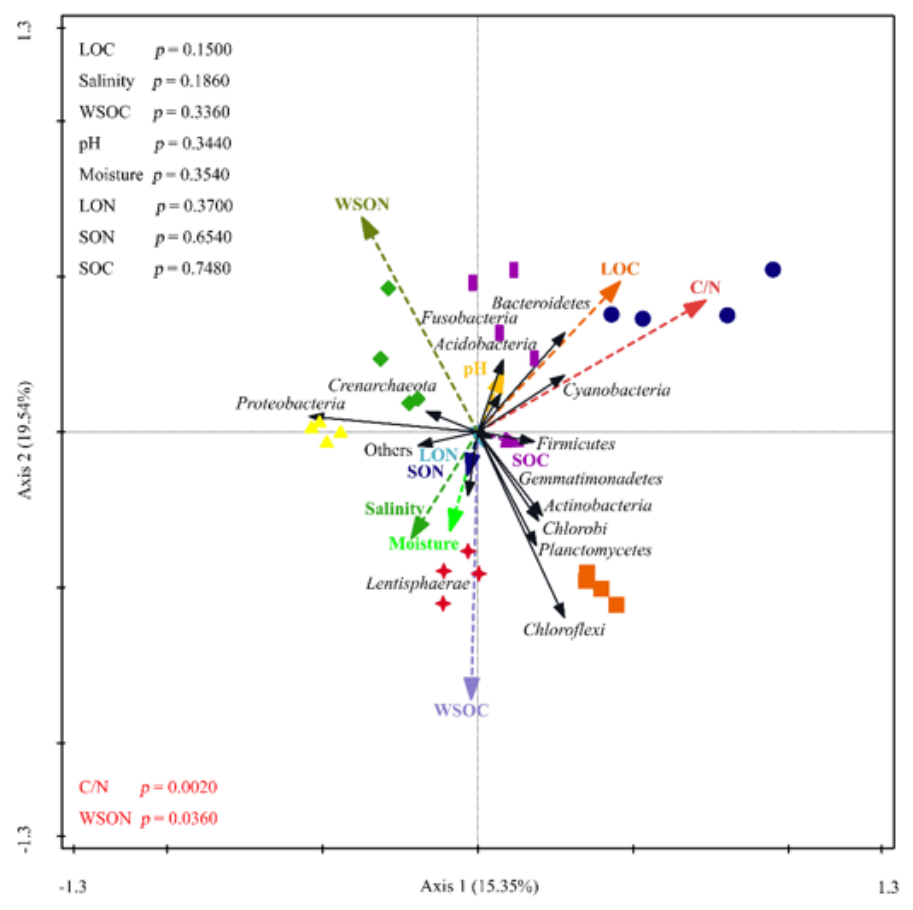

(b)

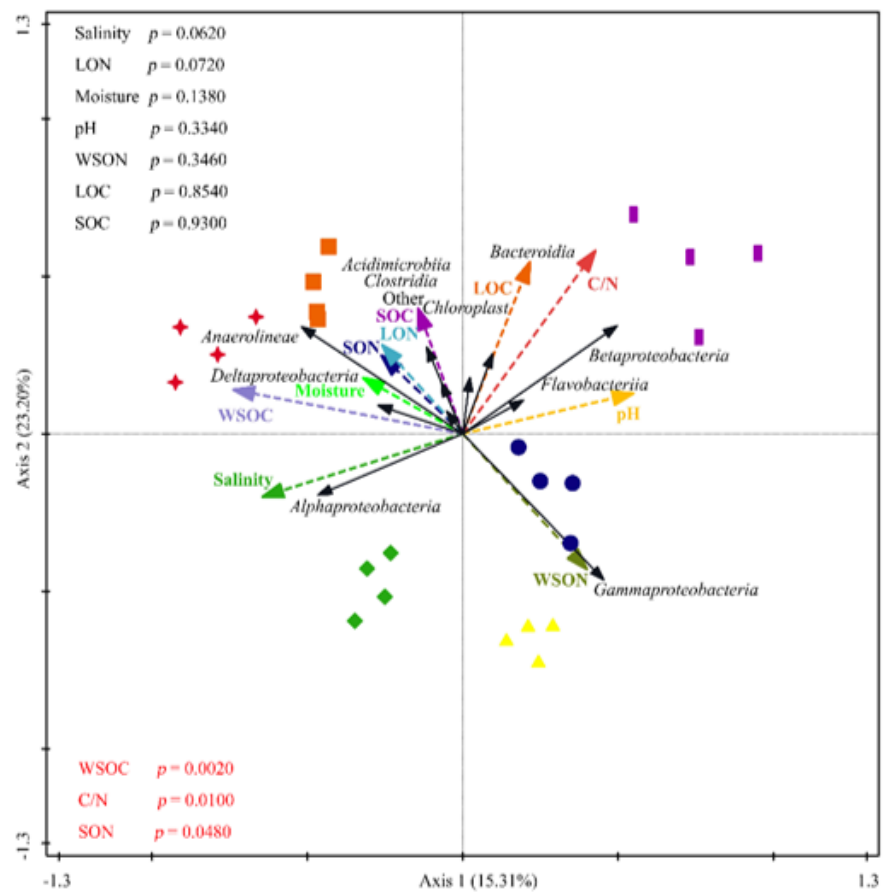

Figure 6

Redundancy analysis (RDA) diagram illustrating the relationship between the compositions of soil bacterial and archaeal salt marshes at the phylum (a) and class (b) level from different sampling sites under variable environments. Solid black arrows show soil bacterial and archaeal community composition; colored arrows show soil moisture, $\mathrm{pH}$, salinity, total organic carbon (SOC), labile organic $\mathrm{C}$ (LOC), water-soluble organic C (WSOC), total organic nitrogen (SON), labile organic $N(L O N)$, water-soluble organic nitrogen (WSON), and carbon-nitrogen ratio $(\mathrm{C} / \mathrm{N})$. 


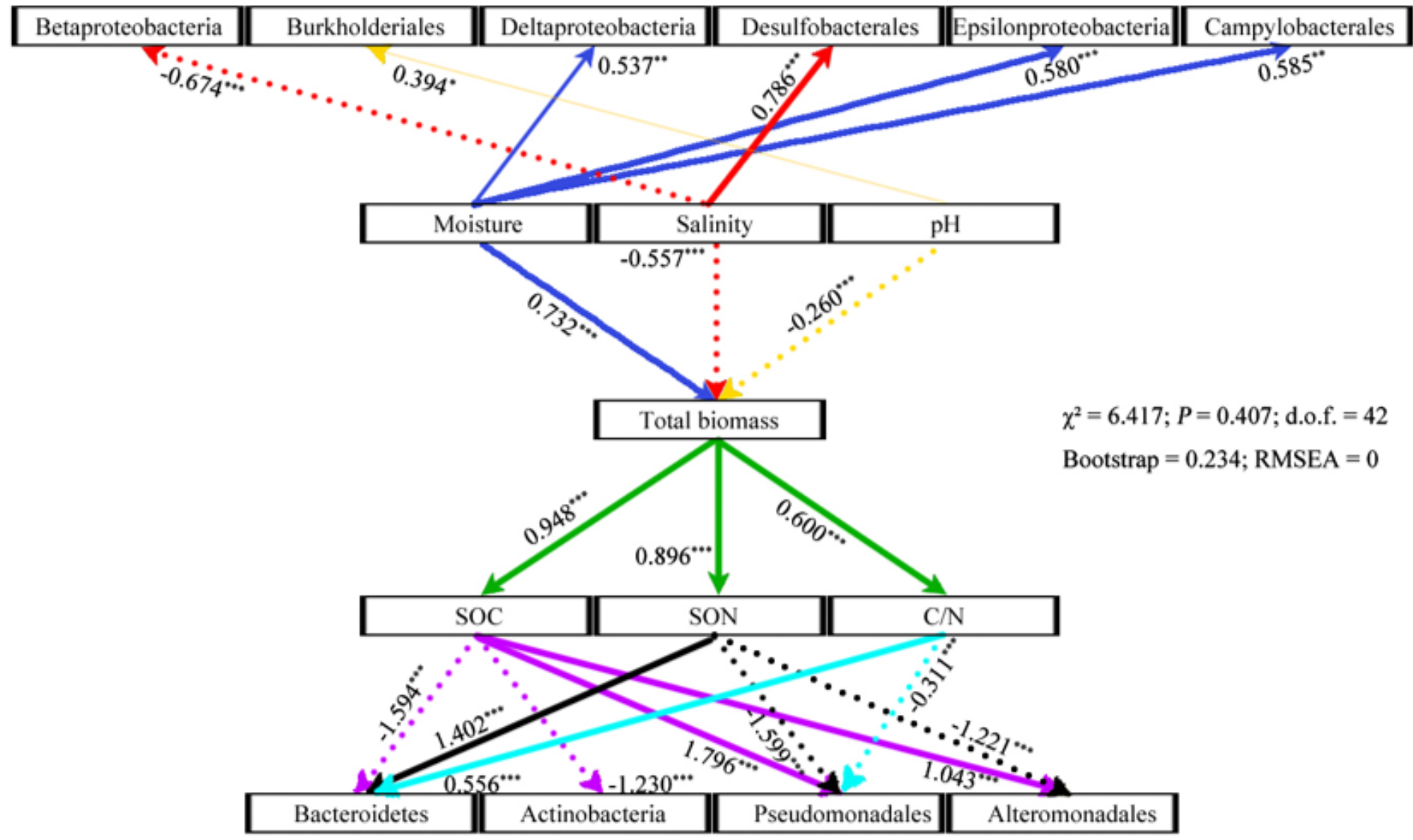

\section{Figure 7}

Structural equation modeling (SEM) examining the effects of soil and plant properties on soil dominant bacteria. Continuous and dashed arrows indicate positive and negative relationships, respectively. Numbers adjacent to arrows are the effect size of the relationships $(*<0.05, * *<0.01, * * *<0.001)$.

\section{Supplementary Files}

This is a list of supplementary files associated with this preprint. Click to download.

- 3SupplementPLSO.docx 